\title{
ENTRE CASTILLA Y FRANCIA: COMERCIO Y COMERCIANTES EN BILBAO A MEDIADOS DEL SIGLO XVI*
}

\author{
LUIS MARÍA BILBAO \\ RAMÓN LANZA GARCÍA
}

Universidad Autónoma de Madrid ${ }^{\mathrm{a}}$

\begin{abstract}
On the basis of a new quantitative data set which is varied, accurate and representative, today it is possible to correct previous shortcomings in order to obtain a solid historical picture of the Atlantic trade passing through the port of Bilbao in the mid-sixteenth century. In this paper we aim to explore both the macroeconomic and microeconomic aspects of Spanish-French trade, analysing, on the one hand, the volume, composition and «balance of trade» and, on the other, the scope and nature of trading enterprises of merchants operating in Bilbao, measurable by the size of their business, the concentration of trade and the amount of business carried out by traders on their own account, in association with other merchants or on behalf of these. We also highlight, once again, the enormous value of judicial sources in the study of trade in the Modern Age.
\end{abstract}

* Received 02/07/2008. Accepted 10/04/2008. Este trabajo es una ampliación revisada de la comunicación invitada al Congreso Internacional Le commerce franco-espagnol a l'époque moderne (Université de Nantes, nov. 2005), para el que se ha contado con la ayuda de sendos proyectos de investigación patrocinados por el Ministerio de Educación y Ciencia, HUM2005-02334, y la Comunidad Autónoma de Madrid, CCG06-UAM/HUM-0213. Asimismo, deseamos expresar nuest ro agradecimiento a los dos evaluadores anónimos y al editor de la RHE-JILAEH, cuyas atinadas observaciones han ayudado a enriquecer el texto final, aunque de los defectos que todavía persisten somos los únicos responsables.

a Departamento de Análisis Económico: Teoría Económica e Historia Económica. Facultad de Ciencias Económicas y Empresariales. Campus de Canto Blanco. 28049 Madrid. luis.bilbao@uam.es y ramon.lanza@uam.es. 
Keywords: foreign trade, trading enterprise, Spain, France, $16^{\text {th }}$ century JEL Classification: N73, N83, F14

\section{RESUMEN}

Una nueva base de datos cuantitativos, variada, precisa y suficientemente re presentativa, permite subsanar las deficiencias documentales hasta ahora existentes para llevar a cabo una re presentación consistente de la estructura del comercio atlántico a través del puerto de Bilbao a mediados del siglo XVI. En este artículo se procede a explorar los aspectos tanto macroeconómicos como microeconómicos del comercio franco-español, mediante el análisis, por un lado, del volumen, composición y «balanza comercial», y, por otro, de algunos perfiles relativos a la naturaleza y alcance de las firmas comerciales que participaban en dicho comercio, como son la cuantificación del volumen de facturación, la concentración del comercio y la comparación entre los negocios llevados a cabo por cuenta propia, en compañía o por cuenta ajena. Asimismo, se destaca una vez más el gran valor de las fuentes de origen judicial para el estudio del comercio en la Edad Modern a.

Palabras claves: comercio exterior, empresa mercantil, España, Francia, siglo XVI

El estudio del comercio exterior en la temprana Edad Moderna tropieza a menudo con graves problemas de documentación. En el caso del puerto de Bilbao el problema alcanza la máxima gravedad porque buena parte del archivo del antiguo Consulado desapareció en las inundaciones de 1593, incluidos todos los registros de averías, que hubieran sido la base de partida para cualquier análisis cuantitativo sólido del comercio bilbaíno. A fin de suplir la ca rencia de información, los historiadores han recurrido de modo ingenioso a diferentes estrategias, como son el análisis seriado de los registros de importación y exportación de los puertos con los que la villa comerciaba y el de las cuentas de la administración de las aduanas exteriores del reino de Castilla, así como la explotación sistemática de los contratos de compraventa que se conservan en los protocolos notariales y el estudio de la correspondencia, los efectos comerciales y la contabilidad de algunas grandes casas de comercio. La suma de todos estos procedimientos, que son compatibles entre sí y que muchas veces han sido empleados a la vez, aunque no están exentos de problemas de representatividad, ha permitido esclarecer un tema que hasta no hace mucho era conocido de forma más bien impresionista ${ }^{1}$. Con todo, la

1 Al libro pionero y clásico de Guiard [1913 (1972)] han seguido los de García de Cortázar (1966), Lapeyre (1956 y 1981); Azaola (1976); Bilbao (1976 y 2003a); Fernández de Pinedo (1998); Priotti (1993 y 2004); Graffe (2005). 
reconstrucción del comercio de Bilbao en el siglo XVI, lejos de haberse agotado, reclama todavía nuevas aportaciones. Por ello seguirá siendo bienvenida cualquier nueva información que ayude a mejorar nuestros conocimientos sobre el tráfico comercial que fluía entre Castilla y la Europa atlántica a través de Bilbao ${ }^{2}$.

El origen de este trabajo se encuentra en el hallazgo de un fondo documental que proporciona nuevos datos cuantitativos, variados y muy precisos sobre el comercio bilbaíno a mediados del siglo XVI, concretamente en los siete años que van desde 1544 hasta $1550^{3}$. Un período de tiempo corto que no admite una reconstrucción de la coyuntura, pero sí un análisis de la estructura del comercio exterior y de los agentes que participaban en el mismo, los comerciantes afincados en la villa de Bilbao. Una de las propiedades por las que destaca el citado documento es que ofrece información simultánea sobre las diferentes direcciones del comercio, cosa bastante poco habitual ${ }^{4}$. Afortunadamente, la fuente que ahora presentamos contiene datos coetáneos del comercio exterior de la Corona de Castilla a través de Bilbao con Inglaterra, Flandes y Francia, que eran los países con los que mantenía intercambios más intensos. Sin embargo, la riqueza y complejidad de la misma fuente implican algunos problemas metodológicos y de economía de medios que aconsejan limitar por ahora el estudio al caso de Francia y posponer para otra ocasión el de las relaciones comerciales con otros países europeos. La elección se justifica asimismo por razones historiográficas, pues los numerosos estudios de que ha sido objeto el comercio hispano-francés y concretamente el papel desempeñado en el mismo por el puerto Bilbao nos ayudarán a comprender en mejor medida el potencial que encierra la fuente que ahora presentamos ${ }^{5}$.

En cualquier caso, el trabajo se ajustará deliberadamente a un análisis teñido de fuerte empirismo, a una representación organizada de los datos, a un tratamiento nada artificioso de los mismos y a una inferencia de conclusiones muy pegada a las evidencias documentales. De este modo pretendemos contribuir con información inédita al debate siempre abierto sobre el volumen, el valor y la estructura del comercio exterior, además del alcance y la naturaleza de los negocios en que participaban los comerciantes asentados en la villa de Bilbao en una época en la que estos temas han sido abordados de una forma necesariamente impresionista debido a la escasez y las limitaciones de las fuentes hasta ahora disponibles.

\footnotetext{
2 Bilbao (2003a, pp. 248-249).

3 Archivo General de Simancas [AGS], Consejo Real [CR], legajo 604.

4 Priotti (2004, p. 66) se lamenta con razón de que «il est bien difficile de déter miner simultanément les échanges de Bilbao avec tous ses partenaires commerciaux».

5 La relación es bien larga, a los estudios citados en la nota primera es necesario añadir también otros, desde el clásico de Tanguy (1956), hasta los más recientes de Casado Alonso (1991 y 2000).
} 
En el orden expositivo, comenzaremos por un apartado de carácter metodológico, un poco largo, pero esencial a fin de exponer el origen del documento que vamos a utilizar, valorar la verosimilitud y representatividad de la información que contiene y explicar los procedimientos llevados a cabo para medir el volumen y el valor del tráfico mercantil. A continuación, y con el fin de situar nuestra investigación en el contexto histórico que le corresponde, trazaremos un breve apunte de la trayectoria que siguió el comercio bilbaíno hasta los años mediados del siglo XVI y su situación respecto a las grandes tendencias que experimentaba el comercio europeo de la época. Después abordaremos lo que constituye el objeto central de este trabajo: en el apartado tercero, ofrecemos un análisis macroeconómico del volumen, composición y «balanza del comercio» de Bilbao, mejor dicho, del comercio entre Castilla y Francia a través de Bilbao en los años de 1544 a 1550 , y, en el cuarto y último apartado, un estudio de algunos perfiles relativos a la naturaleza, alcance y relaciones de los comerciantes que participaban en dicho comercio.

\section{NUEVA FUENTE, NUEVA BASE DE DATOS}

El documento al que aludimos tiene su origen en las actuaciones emprendidas por el corregidor de Vizcaya, Juan Zapata de Cárdenas, y posteriormente por el licenciado Arceo, alcalde de la Chancillería, en cumplimiento de la Real Provisión de 14 de septiembre de $1549^{6}$. El objeto inmediato de la intervención de la justicia real era abrir una «investigación» sobre el alcance que había tomado la ilegal «saca de moneda, oro y plata, de Vizcaya, Guipúzcoa, Salvatierra, Logroño y Álava», a cuyo efecto se mandaba al corregidor de Vizcaya apremiar a los mercaderes residentes en el Señorío y que comerciaban fuera del Reino a que compareciesen ante él con sus libros de contabilidad, de los cuales el corregidor debía encargarse de hacer inventario ante escribano público y de enviar relación al Consejo antes de devolverlos a sus dueños. Las autoridades debieron de advertir que las fuertes entradas de metales preciosos procedentes de América que se registraron por esos años alimentaban unas salidas no menos intensas hacia los países del norte de Europa y muy particularmente hacia Francia, cuyas cecas no por casualidad conocían por aquellas fechas una gran actividad $^{7}$. Los autos del corregidor se iniciaron de inmediato, dirigiéndose a las casas de los mercaderes a tomar relación de sus libros y confiscarlos

${ }^{6}$ AGS, CR, leg. 604, docs. 1 y 6. Labayru [1900 (1968), p. 26] ya hizo re fe rencia a esta Provisión Real y a la documentación que produjo.

7 Sobre esto último, véase Hamilton [1975 (1934), p. 47] y Spooner (1972, pp. 214 y 226230). Conviene recordar asimismo que justamente en 1552 se suspende la tradicional prohibición de exportación de moneda a petición, parece ser, de los asentistas de la Corona, como indica Marcos Martín (2000, pp. 143-146). 
momentáneamente. Y prosiguieron ante el juez Arceo durante todo el año de 1550. Para el mes de diciembre los mercaderes habían presentado las memorias de las operaciones efectuadas con el extranjero durante los años inmediatamente anteriores, "como parece por su libro de caxa», según expresión de Sancho López de Recarte ${ }^{8}$. Toda esta operación dio como resultado las denominadas relaciones de mercaderes, de las que se ha conservado una cincuentena, relaciones creadas, insistimos, a partir de los libros de caja que previamente habían depositado los mercaderes ante la justicia, la cual seguía manteniendo en su poder los libros manuales.

El proceso generó más documentos, pues también se pidió testimonio de las llamadas manifestaciones de extranjeros. Con el fin de apurar la investigación fueron requeridos los escribanos de la villa de Bilbao para que presentaran relación de las manifestaciones que los extranjeros habían pasado ante ellos en cumplimiento de las leyes del Reino, que obligaban a declarar ante el alcalde mayor y registrar ante escribano las mercancías importadas, así como a dar el descargo de las exportadas, cuyo valor debía coincidir con el de aquellas, a fin de garantizar el cumplimiento del ideal mercantilista: impedir la exportación de numerario. La mayoría de los declarantes no son propiamente mercaderes, sino patrones, armadores y huéspedes que operan en nombre o por cuenta de otros. Una tercera y última documentación fue incorporada a la causa al emplazar al Consulado de Bilbao a que presentara la información pertinente, las averías. Por desgracia, solamente se ha conservado una relación de las averías de Nantes, ciudad con la que Bilbao tenía desde antiguo especiales y privilegiadas relaciones comerciales. Estos dos tipos de fuentes pueden ser de gran utilidad a la hora de contrastar la veracidad de la primera, pues se trata de documentos públicos y, en principio, de crédito fuera de toda sospecha.

La información que contienen estos tres conjuntos documentales es diversa pero complementaria. Las relaciones de mercaderes indican las operaciones comerciales llevadas a cabo con Europa durante los años referidos por los comerciantes que residían en Bilbao, cualquiera que fuese su origen o naturaleza. En cuanto que declaraciones juradas de mercaderes con actividades de diverso alcance, conviene aclarar que no todas siguen el mismo formato, razón por la cual ciertos datos no aparecen con el carácter sistemático que sería deseable. Así, todo, la información que contienen resulta

8 Martín de Anuncibay corrobora este dato al referirse a la «Relación que e sacado yo... de mis libros». Diego Pérez de Fuica solicitó al juez que le permitiera consultar el libro manual que le había sido retenido al objeto de poder asentar en él las partidas que estaban en el libro de caja, única información de la que podía valerse para hacer la relación. Otro ejemplo más, entre otros posibles: Pedro Sáez de Arexmendi, alcalde a la sazón de Bilbao, renuente a los requerimientos de la justicia para que presentara libros adicionales al que ya había entregado, se excusaba en declaración hecha el 11 de noviembre de 1550 de no poderlo hacer por haber perdido algunos libros en un incendio que aparentemente había sufrido su casa. Tres días después entregó a la justicia un libro de caja y otro manual, siéndole devuelto el primero. Véase el esquema de o rganización contable de la compañía Salamanca en Casado Alonso (1995, p. 48). 
ser enormemente rica, pues indican siempre las cantidades importadas y exportadas, aunque no sistemáticamente los valores monetarios, siempre también su origen inmediato, pero no el itinerario completo que había seguido desde el lugar de producción hasta su destino en el puerto de Bilbao, muy a menudo señalan también el lugar de venta final, si se trata de mercancías en tránsito o no, y a veces algunos pormenores del transporte. Se consignan igualmente datos relativos a los movimientos financieros, transferencias de dinero entre plazas y ferias castellanas y europeas, así como los instrumentos empleados. A esta información, susceptible de un análisis macroeconómico, se añade otra, no menos interesante, de carácter empresarial, como costes y, sobre todo, la naturaleza de las operaciones realizadas: por cuenta propia, en asociación o compañía de otros, o por cuenta ajena, en calidad de huésped -comisionista o factor, el nombre de cuyo «amo» y "señor» se indica-, información, por tanto, apropiada para un estudio microeconómico sobre la naturaleza de la actividad comercial de los agentes bilbaínos y de las firmas de diverso tipo que operaban en la villa de Bilbao.

Las manifestaciones de extranjeros son por su propia naturaleza más sobrias en información. Pero aparte de ello, las que podemos aprovechar para nuestros propósitos son pocas. De un total de 551 solamente ofrecen información cuantitativa relevante 309, y de éstas sólo 116 indican valoraciones monetarias. Las relativas al comercio franco-español se reducen a 58. La parquedad de datos de la mayoría de ellas impide saber si se refieren o no a la información contenida en las relaciones de mercaderes, aunque su conjunto sirve para verificar la credibilidad de estas últimas por medio de una simple comparación de la estructura del comercio que se deduce de los datos de ambas. La relación de las averías de Nantes informa de las contribuciones que los buques llegados de aquel puerto realizaban al Consulado de Bilbao al objeto de subvenir a los gastos ocasionados por los servicios que éste prestaba. Los cargadores de Nantes contribuían por carga de fardel, lo que nos permite conocer no sólo los fardeles recibidos, sino sobre todo quiénes eran los cargadores titulares en Nantes y sus huéspedes en Bilbao. Para el estudio que nos concierne, la documentación es de impagable interés, pero desdichadamente sólo consta la relación correspondiente a la judicatura de 1545-1546.

Garantizada la fiabilidad de la fuente y su potencial informativo, resta por comprobar su representatividad, habida cuenta de que no se ha conservado sino una parte de la documentación original. Nos referimos a las relaciones de mercaderes, nuestra fuente básica. Una serie de argumentos se concitan a favor de una representatividad más que suficiente, tanto en relación al comercio general de Bilbao con Europa como al desarrollado con Francia en particular. A fin de aclarar este punto y dado que no existen censos de población de la villa antes de finales del siglo XVIII, proponemos hacer las comparaciones siguientes. En Bilbao había con toda seguridad más 
comerciantes que los poco más de 50 citados en la fuente, pero probablemente no muchos más. En comparación con los 256 matriculados en el Consulado durante las judicaturas comprendidas entre 1525 y 1550 que cita Guiard [1913 (1972), pp. 168-170] parecen pocos, la quinta parte. Sin embargo, hay que recordar dos hechos: primero, que esta última es una nómina que abarca un cuarto de siglo, un tiempo demasiado largo en una época de elevada movilidad y corta esperanza de vida como para mantener la actividad comercial sin interrupciones; segundo, que la matrícula, aunque puede no ser exhaustiva, incluye también a navieros, maestres y capitanes de navíos, que formaban parte del Consulado del mismo modo que los mercaderes. En consecuencia, respecto al número de mercaderes en activo en un año dado, la muestra que manejamos debe ser indudablemente mayor que el 20 por cien arriba referido. Por otra parte, si damos por hecho que Bilbao contaba a mediados del siglo XVI con una población de 5.000 habitantes aproximadamente y suponemos que la tasa de actividad y la estructura de la población activa no podía ser muy diferente a la de 1797, cuando la población se había duplicado, entonces, el número de comerciantes residentes en la villa c.1550 difícilmente podía sobrepasar los dos centenares, de los cuales sólo una tercera parte, la misma proprción que dos siglos después, estaría dedicada al comercio exterior al por mayor: es decir, unos 70 individuos poco más o menos ${ }^{9}$. No es ocioso recordar que Medina del Campo, con una población tres veces mayor, contaba en 1561 con 131 mercaderes ${ }^{10}$, que en la ciudad de Burgos, con una población de casi 20.000 habitantes, había en ese mismo año solamente 96 mercaderes dedicados al gran comercio y las finanzas, siendo como era uno de los principales centros mercantiles de España ${ }^{11}$, y que en la todavía más poblada ciudad de Barcelona se han documentado c.1552 unos 148 individuos dedicados al gran comercio $^{12}$. En resumen, ni siquiera en la misma villa de Bilbao podía haber tantos mercaderes como en las ciudades mencionadas. En consecuencia, si las comparaciones son pertinentes, debe inferirse que disponemos de una muestra altamente representativa, superior a la mitad de los mercaderes activos en el puerto bilbaíno a mediados del siglo XVI, estadísticamente suficiente para extraer conclusiones consistentes.

La nómina de comerciantes que aparecen en las relaciones interviniendo en el comercio particular con Francia es lógicamente menor que la general,

9 Mauleón (1960, p. 60). Como refuerzo argumental comparativo se puede traer a colación que las averías del Consulado en el siglo XVIII mencionan 454 comerciantes en 1785, 626 en 1790 y 357 en 1798, de los cuales habría que deducir a los marginales, de modo que solamente quedaría un máximo de 245 y un mínimo de 127, según Zabala (1994, p. 459), pero con una población que duplicaba a la de mediados del siglo XVI y un volumen de comercialización de seguro mayor. Respecto a la situación en 1545-1546, véase más abajo la nota 16.

${ }_{10}$ Marcos Martín (1978, p. 316).

11 González Prieto (2006, pp. 42 y 237-239). Dos décadas antes el número de asistentes al Consulado de Burgos duplicaba esa cifra, pero en 1572 ya se había reducido a la tercera part e.

12 Priotti $(2005$, p. 41$)$. 
24 mercaderes, pero tan robusta o más que ésta. El principal problema de la representatividad radica aquí en la cobertura temporal: no todos operan durante el mismo número de años ${ }^{13}$. La falta de información en algunos años no significa necesariamente que los mercaderes permanecieran inactivos y que no hubieran comerciado, pues algunos confiesan haber estado ausentes de Bilbao pero haber operado por terceras persona ${ }^{14}$. Si los veinticuatro mercaderes hubieran estado en activo sin interrupción durante los siete años anteriores deberíamos tener información, a razón de siete años por cada mercader, de 168 años, pero en realidad solamente la tenemos de 86, de modo que la muestra representa como mínimo el 51 por cien del máximo posible. En realidad, esta proporción debe de ser sensiblemente mayor en los dos años inmediatamente anteriores al de la declaración a que se refiere la Real Provisión.

Dos argumentos adicionales refuerzan la idea de que estamos ante una muestra sobradamente representativa. Las exportaciones de lienzos de Nantes a España desde 1549 hasta 1551 alcanzaron una media anual de 12.592 fardeles, la mayoría de las cuales debieron pasar por Bilbao ${ }^{15}$. A este puerto llegaron en la judicatura de 1545-1546, a tenor de las averías de Nantes, cincuenta naos con un total de 10.183 fardeles procedentes de Nantes, salvo dos que vinieron de Rouen. En comparación con esta cifra, los 20.866 fardeles de ropas que declaran los mercaderes en sus relaciones representan un mínimo del 29 por cien, si damos por supuesto, de modo evidentemente exagerado, que el período de observación abarca siete años, y un 57 por cien, si reconocemos que el periodo medio de observación se limita a 3,58 años por mercader. Teniendo en cuenta, además, que las rela ciones documentadas se concentran en los años finales del periodo y que muchos comerciantes obligados a declarar ya habrían fenecido - hay constancia documental de algunos casos-, la muestra debería ser todavía más alta. El otro argumento se sustenta en el listado de las citadas averías de Nantes de 1545-1546. Evidentemente, no todos los comerciantes en él referenciados aparecen en las relaciones. Pero los que figuran como residentes en Bilbao en ambos documentos (exactamente 13) recibieron en 1545-1546 el 57,08 por cien de los fardeles procedentes de Nantes, cifra a la que es pre-

${ }^{13}$ La muestra, sistematizada, en la que se incluyen tres mercaderes que también comerciaban con Flandes, uno asimismo con Inglaterra y cinco con los tres países, es como sigue:

\begin{tabular}{|l|c|c|c|c|c|c|c|c|c|}
\hline Años de actividad & 1 & 2 & 3 & 4 & 5 & 6 & 7 & Total & Media \\
\hline Número de mercaderes & 5 & 5 & 2 & 4 & 2 & 3 & 3 & 24 & \multirow{2}{*}{3,58} \\
\hline Total años observados & 5 & 10 & 6 & 16 & 10 & 18 & 21 & 86 & \\
\hline
\end{tabular}

14 Bartolomé de Miranda dice expresamente haber estado ausente de Bilbao durante un tiempo en el que las mercancías consignadas a su nombre fueron recibidas por otros socios vecinos de Bilbao, concretamente Juan de Zornoza y Martín de Bertendona.

15 Priotti (2004, p. 77). 
ciso añadir el 5,17 por cien que representan los agentes que entonces operaban como cargadores desde Francia y que luego en 1550 ya se encuentran en Bilbao. Estamos por tanto ante una muestra no inferior al 62 por cien por lo que respecta a este renglón, el más destacado, de las importaciones. Cabe en consecuencia asegurar que la muestra de comerciantes reseñados en las relaciones no sólo sobrepasa la mitad, sino que se trata de los mejo res, los más poderosos y activos ${ }^{16}$.

Se ha adelantado más arriba que la documentación tiene lagunas y no siempre responde al óptimo deseable. Esto ha obligado a hacer estimaciones e interpolaciones. El valor de toda estimación depende del modelo - teórico o contable- en que se funda, de la calidad de la información de que se dispone y de la lógica de las reglas de inferencia seguidas. La laguna más destacable es la relativa a la valoración monetaria de las mercaderías comerciadas. No siempre la documentación da cuenta de estas valoraciones. Nunca en el caso de los libros y el pastel, casi siempre en el del hierro y el acero y muy a menudo en el de los lienzos. Además de lagunar, la información sobre precios es diversa. Para una misma mercancía pueden darse precios correspondientes a los mercados franceses o a los de Bilbao, que a su vez pueden ser precios o bien de compra o bien de venta. En los casos más afortunados podemos comparar el valor de compra de una mercancía en origen y el de su venta en destino y medir el valor añadido de distribución ${ }^{17}$. En estas condiciones documentales, de ausencia de valoraciones y diversidad de precios, se ha optado, en primer lugar, por estimar el valor monetario de las mercancías no directamente valoradas en el texto y, en segundo lugar, se ha planteado el problema de la elección entre los diferentes precios documentados.

La estimación del valor de las mercancías se ha llevado a cabo o bien con precios medios ponderados de las declaraciones de cada uno de los comerciantes, cuando éstos ofrecen una valoración no total sino parcial de dicha mercancía, o bien con precios medios ponderados generales deducidos del conjunto de la documentación sobre la mercancía en cuestión, cuando las declaraciones particulares no indican valoración alguna de la misma. En

16 Uno de los principales huéspedes que aparecen en las averías de Nantes es Martín de Bertendona, cuya relación consta por testimonio notarial haber sido entregada, aunque, por desgracia, no se encuentra entre los documentos del proceso judicial: AGS, CR, leg. 604. En 15451546 recibe más del 15 por cien de los fardeles procedentes de Nantes, de modo que de haberse conservado, la muestra habría alcanzado por este lado casi el 80 por cien del total. En la tabla 4 puede verse que los huéspedes son 58 , pero los que realmente cuentan en el comercio con Nantes son esos 18 que reciben el 91,25 por cien de todos los fardeles.

17 La anotación de esta importantísima información depen de muy probablemente del papel que desempeñaba el mercader en el proceso de comercialización: si era un agente activo podía conocer los precios de origen, pero si se trata de un mero comisionista sólo podrá anotar los precios de venta de aquellas mercancías que realizaba inmediatamente para disponer de liquidez con que pagar las costas más imprescindibles, como fletes, estiba y transporte, almacenaje y averías. 
los casos de otras mercancías para las que el documento no ofrece valoraciones, las menos y más marginales, ha sido preciso recurrir a información ajena al documento ${ }^{18}$. Se ha buscado con este ejercicio optimizar la verosimilitud de la estimación.

El segundo punto está relacionado con la contabilidad de la balanza de pagos y requiere una breve pero importante aclaración. El modelo de contabilidad del sector exterior que hoy se recomienda aspira a homogeneizar las partidas contables y eliminar sesgos en los balances, si bien este óptimo no siempre es factible ${ }^{19}$. Por ello sigue siendo aún habitual expresar el valor del comercio exterior en importaciones CIF (Cost, Insurance and Freight) y en exportaciones FOB (Free on Board), aunque este método incorpora inevitablemente un sesgo en las balanzas que tiende a sobrevalorar las importaciones. Por esta razón se aconseja, primero, que los valores monetarios se expresen estrictamente a precios de mercado y, segundo, a precios, a ser posible, de compra, mejor controlados que los de venta, excluyendo costes de transportes y otros, con todo lo cual se elude el llamado agujero negro de las contabilidades nacionales exteriores. Siguiendo este criterio, que proporciona un óptimo desde el punto de vista técnico y metodológico, es deseable contar siempre con los precios de compra en Bilbao de las exportaciones a Francia y con los de Francia respecto a las importaciones por Bilbao $^{20}$.

${ }^{18}$ En el caso del pastel nos valemos de los precios correspondientes a las partidas embarcadas por Diego Bernuy en Burdeos el año 1546, que ascendieron a 2.020 maravedíes por carga según Casado (1991, pp. 339-340). Algunas partidas sin especificar o genéricamente definidas como "cargazón», pocas, han sido incorporadas en el apartado de varios junto con mercancías de escasa importancia.

19 Nos referimos al modelo recomendado por el Fondo Monetario Internacional. Cfr. Sánchez Muñoz (2007), a quien agradecemos las sugerencias que ha hecho a nuestra consulta.

$20 \mathrm{Ni}$ Azaola (1976) ni Priotti (2004) se han cuestionado nada al respecto en sus estimaciones del comercio franco-español, cuando han utilizado respectivamente precios de Nantes y de Bilbao para valorar tanto importaciones como exportaciones. La localidad objeto de estudio en modo alguno debe dict ar la elección de los precios. Esta opción provoca necesariamente sesgos de distinto sentido en los balances, que en buena lógica económica deben ser, cuando menos, advertidos. Las estimaciones de Priotti (2004, pp. 73-79) sobre el valor del comercio exterior bilbaíno c. 1560 resultan por ello sensiblemente elevadas, aparte de que los precios de las mercancías más importantes del comercio hispano-francés que maneja, lencería, lanas y productos siderúrgicos en Bilbao (columna 1 del cuadro de esta nota), sobrepasan con creces los que ofrecen otras fuentes de épocas próximas, como son: las relaciones de mercaderes de 1544-1550 (columna 2); los roles de precios que según los comerciantes del Consulado «comúnmente suelen valer» las mercaderías que «comúnmente suelen salir y venir por la dicha barra» de Bilbao, elaborado uno en 1553 (3) y el otro en 1563 (4), datos que proceden de Guiard [1913 (1972), pp. 185-197], y Labayru [1900 (1968), pp. 283-284]; la estimación de Azaola (1976, pp. 791-792), con precios de Nantes en los años 1550 (5), expresados en libras tornesas y convertidos aquí a maravedíes al tipo de cambio de 200 maravedíes por libra que aparece en la relación de Diego Pérez de Fuica cuando se refi e rea los giros con las ferias de Lyon en los años de 1542 a 1548; y, por último (6), los precios de las manifestaciones de 1567 a 1578, años de ya fuerte inflación, del comerciante francés Xiles Perrin, que se puede consultar en AGS, CR, leg. 602 , doc. 6 . 
La valoración de las exportaciones no plantea problema alguno al respecto, dado que podemos utilizar los precios de mercado en origen, Bilbao. En lo que atañe a las exportaciones más importantes cuantitativamente hierro, acero y lanas- se ofrecen casi sistemáticamente los precios de compra más los costes del transporte hasta puerto - lo que «costaron hasta cargados»- Ahora bien, ¿cuáles son los precios más adecuados a la hora de cuantificar el valor de las importaciones? Los de Bilbao incluyen costes, fletes y seguros, pero no por eso deben confundirse con importaciones CIF porque, siendo precios de venta, incorporan también los beneficios empresariales. Lógicamente hemos decidido prescindir a este respecto de los precios bilbaínos y utilizar los correspondientes al puerto francés de origen de la mercancía.

Asegurada la fiabilidad de la fuente y la calidad de su información, así como explicitado el modelo contable que se ha de emplear, podemos proceder con las estimaciones pertinentes. La incertidumbre acerca de la amplitud exacta de la muestra que manejamos en modo alguno resta valor a la información disponible, es más, puede afirmarse tras las pruebas aducidas que la representatividad es más que notable, por encima de lo estadísticamente exigible, máxime cuando lo que se pretende es analizar la composición o estructura de los intercambios, el sentido de la «balanza comercial», el papel de los mercaderes en cuanto agentes activos o comisionistas y la escala de sus operaciones. En realidad, de momento no interesa tanto el nivel absoluto del volumen o valor de los flujos cuanto los ó rdenes de magnitud relativos. La reconstruxción del valor total del comercio exterior a través de Bilbao puede ser tan problemática que resulte en la práctica imposible, al menos por el momento, a través de esta fuente documental.

Una doble advertencia para terminar este comentario sobre la documentación. En las relaciones de los mercaderes apenas se advierten intercambios de carácter triangular, salvo unas pocas partidas de origen flamenco, de modo que puede afirmarse que estamos ante un comercio fundamentalmente bilateral, lo que facilita el análisis. Por otra parte, los años en que discurren las operaciones fueron aparentemente normales, en el sen-

\begin{tabular}{|l|c|c|c|c|c|c|c|}
\hline & Unidades & \multicolumn{7}{|c|}{ Precios (maravedises) } \\
\hline & & {$[\mathbf{1}]$} & $\mathbf{[ 2 ]}$ & {$[\mathbf{3 ]}$} & $\mathbf{[ 4 ]}$ & [5] & [6] \\
\hline Hierro & tonelada & & 10.388 & 8.956 & 7.610 & & 12.906 \\
\hline Acero & tonelada & & 15.141 & 17.116 & 12.535 & & 19.530 \\
\hline Hierro y acero * & tonelada & 20.446 & 13.734 & & & 14.000 & 13.763 \\
\hline Lienzos & fardel & $22 / 40.000$ & 11.540 & $10 / 25.000$ & & 15.000 & 17.660 \\
\hline Lana & saca & 19.980 & 5.433 & 7.500 & & 13.000 & \\
\hline
\end{tabular}

* Carga mixta, mucho más hierro que acero. 
tido de que los intercambios comerciales no sufrieron las perturbaciones de naturaleza política o militar, tan habituales en la época ${ }^{21}$.

\section{UN MOMENTO DE NUEVAS OPORTUNIDADES: CAMBIO Y CONTINUIDAD DEL COMERCIO EXTERIOR A MEDIADOS DEL SIGLO XVI}

El momento coyuntural de nuestro análisis se inscribe dentro de una tendencia secular alcista que arranca desde el año 1450 aproximadamente. Es en torno a esta fecha clásica del siglo XV cuando se inicia la reactivación de la economía europea, incluida la del comercio a larga distancia, querecobra su senda de crecimiento y experimenta además notables mutaciones respecto a los siglos medievales. El comercio en Europa se relanza a raíz de los cambios surgidos tras la depresión de la Baja Edad Media, pero sobre todo cambia su composición en concordancia con los nuevos patrones de consumo y se multiplican sus direcciones, dilatándose y haciéndose más tupidos los circuitos comerciales. El carácter típicamente suntuario del comercio medieval cede pro g resivamente y por sus circuitos transitan cada vez más productos primarios, bienes alimenticios y materias primas o bienes intermedios industriales, bienes en suma más competitivos y complementarios entre las economías de los nacientes estados nacionales europeos, que disponen de muy diversa dotación de factores. Los circuitos comerciales conocen asimismo importantes cambios. El eje del comercio medieval, la carrera del Norte, de Italia a Flandes e Inglaterra, amén de los países nórdicos, se c ruza con otro de más reciente creación, que va de Este a Oeste enlazando la Europa central y oriental —agraria, poco urbanizada y atrasada- y la occidental —industriosa, urbanizada y más desarrollada-, y abriendo una incipiente, aunque tímida, división del trabajo que se percibe en el comercio de granos, el producto más importante en valor de los que circulan en los mares del norte de Europa. Ambos circuitos se unen en el Atlántico, haciendo fortuna inicialmente en Brujas, luego en Amberes y finalmente en Amsterdam, y enlazan a su vez con las Indias a través de Sevilla y Lisboa.

Además, los intercambios adquieren con el descubrimiento del Nuevo Mundo, las nuevas vías de acceso a las Indias orientales y la conexión entre América y Asia a través del Pacífico una expansión territorial de dimensiones definitivamente planetarias. El comercio intercontinental, de bienes por lo común de lujo y no competitivos, a contrapunto del europeo, también crece gracias en parte a la oferta de mayores medios de pago provenientes

\footnotetext{
21 Cuando las hay, como algún ocasional ataque corsario a la entrada del puerto de Nantes, los textos lo denuncian, cosa que ocurre contadísimas veces. Tampoco hay especiales intervenciones de política comercial que obstaculicen los intercambios por parte de las autoridades castellanas o francesas. Guerra contra Francia y regulaciones comerciales se producirán poco después de terminadas las manifestaciones en agosto de 1551.
} 
del flujo de metales preciosos americanos y japoneses, que facilitan la financiación de una creciente demanda de productos de lujo del Lejano Oriente. Los mercados alcanzan por ello una mayor integración e interdependencia, aún débil, si la medimos con criterios de convergencia de precios, pero más intensa que nunca, si aplicamos otros criterios. En este proceso, que marcará con novedoso sello el nacimiento del comercio mundial en el siglo XVI, Europa ocupa una de las posiciones centrales, y dentro de ella, España y Portugal, como protagonistas iniciales del mismo, desempeñan un papel principal. España como poseedora y proveedora de medios de pago garantiza en una importante medida el funcionamiento del nuevo sistema mundial de comercio.

Como resultado de la incorporación de nuevas regiones al comercio europeo se produce una más intensa integración económica que será especialmente provechosa para las ciudades portuarias. Las instituciones feriales medievales, incapaces de responder con su sistema de encuentros periódicos al volumen y frecuencia de los intercambios, deben adaptarse reteniendo las funciones de ferias de pago, pero ceden las operaciones propias de las ferias de mercancías a las ciudades marítimas, que se convierten así en mercados internacionales permanentes.

En un entorno comercial de intenso cambio, los puertos cantábricos, Bilbao entre ellos, cuentan con ventajas y oportunidades para afrontar con expectativas de éxito la nueva etapa que se abre en los siglos XV y XVI. En primer lugar, por su situación geográfica, que proporciona una evidente renta de posición en el mismo viejo eje comercial Norte-Sur. Esta oportunidad, en segundo término, se refuerza con el dinamismo que experimenta uno de los puntos del polo sur de este eje, Castilla. La meseta conoce en el siglo XV una temprana reactivación económica que prosigue hasta poco más allá de mediado el siglo xvI. La coyuntura de crecimiento se hace acompañar por una mayor división del trabajo, que se aprecia en la difusión de múltiples actividades manufactureras, en especial de la industria textil, y en la implantación de una cada vez más densa red comercial. Los puntos de distribución, ferias y mercados, se multiplican por pueblos y ciudades y las redes comerciales se amplían y vinculan de forma escalonadamente ordenada desde las áreas rurales hasta los grandes polos del comercio internacional. Las ferias de Medina del Campo, Medina de Rioseco y Villalón se convierten en los puntos donde confluyen la red nacional y el comercio de la fachada noratlántica que transita a través de los puertos cantábricos.

Este proceso de integración de la economía castellana con la europea constituye justamente una oportunidad para los puertos del Cantábrico desde Galicia hasta Guipúzcoa. Al fin y al cabo, el comercio de larga distancia había constituido la razón de ser de su fundación como entidades urbanas en la Baja Edad Media, entre ellas la de Bilbao en $1300^{22}$. Su

22 Lanza (1997, p. 180). 
comercio tiene durante el siglo Xvi básicamente un doble motor doméstico en la vertiente exportadora, la lana castellana y el hierro de las regiones cantábricas. Habituales ya en el comercio medieval, los cambios ocurridos en la composición de los intercambios colaboran a impulsar aún más su desarrollo, como materias primas o intermedias industriales que son. El consumo de lana castellana aumenta promovido por el desarrollo de la pañería ligera y la nueva pañería europeas, que exigen materias primas de calidad diferente a la inglesa. La lana castellana, embarcada en los puertos cantábricos, desde Santander a San Sebastián, se dirige como antaño a Flandes y Francia, pero también a un nuevo mercado, Inglaterra. El consumo de hierro también se multiplica gracias al crecimiento económico y su demanda moviliza los grandes hogares siderúrgicos de Europa dotados con factores para su producción. A estos productos se añaden a partir de los años cuarenta los de la pesca de altura, las capturas de bacalao y la caza de la ballena en Terranova, dirigidos, como auténtica industria de exportación, hacia Castilla, Navarra y Aragón. Éstos son los principales productos domésticos exportados a través de los puertos del norte de Castilla, pero no los únicos, junto a ellos hay toda una miscelánea de bienes de menor entidad en peso y valor, y géneros de reexportación, originarios de Europa, América o Asia, como las especias. El crecimiento de todos estos flujos, consistentes en su inmensa mayoría en productos pesados o voluminosos, tira del transporte y de todos los demás servicios portuarios que se incrementan al ritmo que impone el comercio. Un comercio por demás crecientemente cosmopolita, cuyos protagonistas son castellanos, en especial burgaleses, y vascos, pero también extranjeros: franceses, ingleses, flamencos, hanseáticos.

Se puede conjeturar, con fundamento en la investigación hoy disponible, que esta fase de crecimiento comercial empieza a ceder hacia los años cincuenta del siglo XVI. Hilario Casado sentencia: «el esplendor comienza a resquebrajarse a partir de 1550», refiriéndose al comercio controlado por el Consulado de Burgos en el Cantábrico ${ }^{23}$. Hay suficientes indicios para presumir que los problemas del comercio de Burgos y sus adherentes en otras regiones del Cantábrico son a partir de entonces sensiblemente mayores que los de Bilbao. La crisis sería aquí menos violenta y el cambio de tendencia algo más tardío ${ }^{24}$, pero los años en torno a 1550 marcan un punto de no retorno de la coyuntura de bonanza generalizada del comercio atlántico europeo ${ }^{25}$.

${ }_{23}$ Casado (1994, p. 223). La coyuntura de los puertos cántabros lo confirma, según Lanza (2002, pp. 120-124)

${ }^{24}$ Bilbao (2003a, pp. 262-271); Priotti (2004, pp. 145-150); Graffe (2005, pp. 56-57).

${ }^{25}$ La fase expansiva del comercio inglés se detiene también en esos años. Según Rorke (2006, p. 284), «In the second half of the sixteenth century English trade stagnated, yet diversified into new markets and products that became vital in the following century». 
A lo largo de este periodo secular de crecimiento económico y comercial de las regiones del Cantábrico fue consolidándose la estructura del comercio bilbaíno en un determinado sentido que conviene ya especificar, y que desde fines del siglo XVI y lo largo del XVII se irá modificando, a la búsqueda de nuevos mercados y/o productos ${ }^{26}$. Mercados y productos son justamente componentes básicos de la estructura de todo comercio: los merca dos de los que se surte y a los que abastece, los productos con los que comercia, así como el control que se ejerce sobre los diferentes flujos comerciales y el saldo de la «balanza comercial». Para el estudio que nos ocupa conviene reparar en estos elementos y en sus relaciones, que en lo esencial no escapan del escenario dibujado para el conjunto cantábrico pero que incluye singularidades que conviene retener.

Los mercados entre los que intermediaba la villa de Bilbao, teniendo en cuenta su posición geográfica, eran su propio mercado interior y el de las provincias vascas, los mercados exteriores próximos de Castilla y Aragón y los más lejanos de la Europa atlántica o mediterránea, así como la América colonial, en este caso a través de Sevilla. La plaza de Bilbao tenía en efecto establecidas relaciones comerciales con muchas regiones de Europa y España, pero en forma distinta en cuanto a su intensidad y a la diversidad de productos comerciados.

En punto a productos, Bilbao, como cualquier plaza comercial, operaba con productos propios y ajenos, replicando con matices lo descrito para los puertos cantábricos. Entre los propios figuraban desde siempre y sobre todo los de la siderurgia primaria, hierro y acero en barras, y apenas los de la siderurgia ligera y trasformados metálicos. Bilbao era el principal puerto exportador de hierro y acero del Cantábrico en dirección a Europa, por encima de Santander o San Sebastián, parte de cuyas comarcas productoras lo expedían al exterior vía Bilbao ${ }^{27}$. Los productos de la pesca de bajura y especialmente de altura — ballena, bacalao y arenque-, en la medida que eran fruto de capturas propias, deben figurar desde mediados del siglo XVI en segundo lugar y como propios, con la particularidad de que su destino era el interior peninsular y de que Bilbao era también el principal puerto cantábrico de internación de pescado hacia Castilla, Navarra o Aragón ${ }^{28}$. La relación de productos ajenos es amplia y cambiante, pero entre ellos, por su importancia en volumen y/o valor, ha de reseñarse, del lado de las reexportaciones, las especias, de origen portugués, y en las exportaciones, las lanas castellanas, con la advertencia de que Bilbao no fue en el siglo XVI un importante puerto lanero, como entonces lo era Santander y en los siguientes siglos sería el propio Bilbao. En las importaciones de Europa, figuran ante todo tejidos de lana y lienzos, que o se retenían en el

${ }^{26}$ Bilbao (2003b, passim) y (2004, pp. 165 y ss.); Grafe (2005, pp. 108 y ss.).

27 Bilbao (2003a, p. 248).

28 Bilbao (2003a, pp. 245-246). 
propio mercado bilbaíno y vasco o transitaban hacia los mercados castellano, navarro o aragonés. Además, hay que reseñar determinados metales y cera, aparte de cereales panificables y vino, éstos imprescindibles en una tierra agrícolamente pobre, como era la vasca, y cuyo origen eran tanto Europa como la España interior.

Si fundimos las imágenes de mercados y productos, el patrón comercial de Bilbao en cuanto a las principales direcciones y la composición del comercio puede así especificarse sintéticamente: en dirección a Inglaterra, por Bilbao se expedían productos siderúrgicos y algo, aún poco, de lana y se recibían tejidos y paños, principal renglón de las importaciones, así como cuero, plomo y estaño; Flandes era entonces el principal destino de la lana castellana, pero Bilbao, se reitera, no era a la sazón un importante puerto lanero, si bien el primer destino de la lana embarcada en su puerto era asimismo Flandes; la exportación de hierro y acero ocupaba en esta dirección como en otras el puesto principal; de los Países Bajos se importaban tanto tejidos de lana como lienzos, además de importantes cantidades de cera y también cobre. Francia no era por lo general un destino relevante de la lana castellana, pero sí lo era del hierro vasco, que se intercambiaba por productos bastante variados: lienzos, de forma destacada, pero también pastel, papel, naipes, libros y mercería en general. Bilbao tenía así establecidas importantes conexiones comerciales con Europa y Castilla, siendo el principal puerto cantábrico por lo que respecta al volumen y valor de su comercio, que era más de importación que de exportación, constituyéndose por ello en el principal puerto de tránsito de los flujos comerciales que circulaban entre la Europa noratlántica y Castilla.

No es imaginable que sobre este variado espectro y origen de flujos los hombres de negocios de la villa ejerciesen un control comercial absoluto. El comercio bilbaíno no tenía por qué ser necesariamente de este tipo, como no lo era en ninguna de las plazas europeas. La presencia de comerciantes castellanos y extranjeros hace más bien suponer que este control no fue total ni posiblemente homogéneo, dependiendo de productos, circuitos comerciales y momentos históricos ${ }^{29}$. El grado de control comercial se erige en elemento determinante de cualquier estructura de comercio. Y el saldo de la «balanza de comercio» constituye asimismo otro importante componente de la misma. Máxime cuando el conocido déficit de la balanza de comercio castellana suponía la consecuente exportación de capital. El saldo de los flujos reales apela a los financieros, de los que la economía castellana disponía y las europeas escaseaban, reequilibrándose los balances respectivos. Este equilibrio era imprescindible para el buen funcionamiento del naciente comercio mundial, en el que España jugaba un papel clave gra-

${ }^{29}$ Al respecto conviene hacer una doble distinción: entre comercio de tránsito y retenido y entre comercio en sentido pleno, activo o íntegramente controlado, y el ejercicio subsidiario de actividades comerciales al servicio de otros. 
cias a la posesión de metales preciosos. La saca de moneda -origen de nuestra fuente documental - constituía un problema para Castilla, pero una necesidad para Europa.

«Bilbao —-según escribiera Lapeyre hace años- está mucho más relacionada con Francia» ${ }^{30}$. Ello no significa que este circuito fuera más importante que los otros en términos de valor. En el estado actual de nuestros conocimientos es aún prematuro hacer una proposición de tal guisa. Pero Francia era sin duda un punto de notable interés en el conjunto de las relaciones comerciales bilbaínas, pues hacía, en plástica expresión de Priotti, de "plaque tournante», de plataforma comercial, desde Normandía y Bretaña, para los intercambios indirectos, mediando economías de alcance y comercios triangulares, entre Castilla, los Países Bajos e Inglaterra, así como la Europa nórdica y báltica ${ }^{31}$. A pesar de las especiales relaciones que mediaban entre Bilbao y Francia, especialmente a través de Nantes ${ }^{32}$, otros puertos cantábricos y vascos concurrían con Bilbao en dicho comercio. Santander «aparece dedicado casi exclusivamente a la importación de pastel» tolosano, y otro tanto en Laredo ${ }^{33}$. Guipúzcoa disponía de un doble circuito comercial con Francia, el marítimo y el terrestre, que en parte compartía con Navarra. No empero, Bilbao era en el siglo XVI el principal puerto de los intercambios entre Castilla y Francia ${ }^{34}$.

El contexto del comercio europeo y la estructura descrita del comercio bilbaíno a mediados del siglo XVI que se deduce a partir de la literatura hasta hoy disponible, puede ahora confirmarse y sobre todo medirse y por lo mismo especificarse, apoyados en la nueva base de datos construida para analizar el comercio franco-castellano.

\section{EL COMERCIO: COMPOSICIÓN Y «BALANZA COMERCIAL»}

Las estimaciones sobre la composición del comercio que se deducen de los nuevos datos disponibles confirman en parte la imagen ofrecida por viejas y nuevas investigaciones, si cabe con una precisión cuantitativa mayor que hasta ahora. El rasgo fundamental del comercio exterior con Francia a través de Bilbao era el de un doble monocultivo de exportación e importación: predominio de los productos siderometalúrgicos en las exportaciones y de los lienzos en las importaciones. El puerto de Bilbao era, además, desde la perspectiva de este circuito comercial, un puerto esencialmente de importación, a la vista de su abultado déficit comercial.

30 Lapeyre (1981, p. 929)

1 Priotti (2004, pp. 97-100).

32 Tanguy (1956, p. 72-76); Priotti (2004, pp. 99-101).

33 Lapeyre(1981, p. 92).

${ }^{34}$ La contabilidad de los diezmos de la mar y de rechos de lanas lo avala, según Bilbao (2003a), pp. 247-249. 
TABLA 1

LAS EXPORTACIONES, 1544-1550

\begin{tabular}{|l|c|c|c|c|}
\hline \multicolumn{1}{|c|}{ Productos } & Cantidades & Unidades & Maravedíes & $\%$ \\
\hline Hierro y acero & 18.498 & quintales* & 19.296 .320 & 77,86 \\
\hline Lana & 360 & sacas & 1.955 .751 & 7,89 \\
\hline Especias & 21.243 & libras & 2.533 .615 & 10,22 \\
\hline Grasa de ballena & 278 & barricas & 506.480 & 2,04 \\
\hline Sardinas & 19 & barricas & 156.523 & 0,63 \\
\hline Paños & 34 & unidades & 68.864 & 0,28 \\
\hline Muelas & 189 & unidades & 42.328 & 0,17 \\
\hline Cera & 131 & quintales & 31.763 & 0,13 \\
\hline Sombreros & & & 12.920 & 0,05 \\
\hline Varios & & & 179.966 & 0,73 \\
\hline Total & & & $\mathbf{2 4 . 7 8 4 . 5 3 0}$ & $\mathbf{1 0 0 , 0 0}$ \\
\hline
\end{tabular}

* Quintal macho = 155 libras castellanas de 490 gramos = 75,95 kilogramos.

Tal y como se evidencia en la tabla 1, en las exportaciones predominan, con el 78 por cien del valor de las mismas, los productos siderúrgicos, fabricados en el propio País Vasco y no necesariamente en áreas próximas al mismo Bilbao. De su puerto sale hierro procedente tanto de Vizcaya como del noroeste alavés y de las comarcas occidentales de Guipúzcoa por un volumen total de 18.500 quintales, equivalentes a $1.480 \mathrm{Tm}$. Se trata de acero y, sobre todo, de hierros de diversas clases y precios, semielaborados en barras, los denominados hierros comerciales, pero apenas nada de piezas elaboradas, clavazón o herraje, productos, en fin, mayoritariamente de la siderurgia primaria, bienes por tanto intermedios, de valor añadido consecuentemente medio ${ }^{35}$. A ellos siguen, pero a distancia, la lana (8 por cien), materia prima industrial de menor valor añadido que el hierro y de indudable origen castellano, y las especias (10 por cien), principalmente pimienta, de origen probablemente portugués, producto por tanto de reexportación. El resto (4 por cien) lo compone una miscelánea de productos varios, entre los que destaca la grasa de ballena. Se trata, en suma, de bienes en su inmensa mayoría primarios o intermedios, de valor añadido medio y bajo.

En esta imagen hay dos ausencias, o escasa presencia, que reclaman una explicación. Del lado de las importaciones, la presencia marginal, práctica-

35 Bilbao era el primer abastecedor de hierro y acero de Francia, muy por encima de Inglaterra, al menos lo era de Nantes, según Tanguy (1956, pp. 26-28). 
mente ausencia, de productos alimenticios, salvo pescado, y en las exportaciones, las reducidas cantidades de lana expedida, lo que puede defraudar expectativas fundadas en que «las lanas ocupaban el primer lugar de las importaciones» españolas en Francia ${ }^{36}$. Los anecdóticos registros de granos y leguminosas, que tradicionalmente se importaban en un territorio agrícolamente deficitario, podrían explicarse, sin más pretensiones que la mera suposición, o bien porque otros países diferentes a Francia eran entonces los abastecedores, o bien porque todavía no se experimentaba una situación de dependencia respecto a los suministros externos, como ocurrirá más tarde ${ }^{37}$. Ante las magras expediciones de lana, conviene recordar que ni Francia era un gran importador ni Bilbao era entonces, ni lo será por tiempo, un importante puerto de embarque de esta mercadería. En aquellas fechas y en el Cantábrico lo era Santander, donde sintomáticamente tenía residencia el administrador del nuevo derecho de lanas ${ }^{38}$. De las 86.000 sacas que entre 1562 y 1566 se expidieron por los puertos cantábricos hacia Europa, sólo se dirigieron a Francia 3.750, de las cuales pasaron por Bilbao $1.017^{39}$, lo que hace una media anual de 203 sacas. Las 360 remitidas a Francia según la muestra que manejamos de los años 1544 a 1550 equivalen a 51 ó 100 sacas por año, según tomemos de media los 7 ó 3,58 años de observación a que nos referíamos anteriormente ${ }^{40}$. Se desconoce cuál era el volumen total de lana española exportada a Francia en las fechas de nuestro estudio, así como la magnitud de las embarcadas en Bilbao, si bien parece que debieron de ser más que después de 1558, fecha de subida de aranceles en Castilla ${ }^{41}$. Con todo, la fuente da testimonio de que la remesa fue superior a las 360 sacas referidas: Martín de Anuncibay manifiesta haber exportado lana, pero sin indicar volumen, valor ni puerto de embarque, lo que imposibilita cualquier estimación, y Bartolomé de Miranda declara que María de Miranda había remitido 102 sacas, partidas ambas que no pueden ser computadas en este estudio.

La tabla 2 muestra que en las importaciones prevalecen los lienzos, de distintos orígenes y de muy variadas calidades y precios. Más de 20.000 fardeles y paquetes embarcados en su mayoría en Nantes, los cuales representan el 72 por cien del valor total de las importaciones; a ellos siguen casi 23.000 balas de pastel, de origen tolosano y embarcadas en Burdeos (22 por

6 Azaola (1976, p. 792).

37 Graffe (2005, pp. 53-55) (1997).

Bilbao (2003a, p. 247). Cfr. Lapeyre (1981); Bilbao y Fernández de Pinedo (1994); Phillips

${ }^{39}$ Lapeyre(1981, pp. 202-204).

40 Por tanto, re presentan un mínimo poco probable del 25 por cien y un máximo más verosímil del 64 por cien de las sacas exportadas en 1562-1566.

41 Según Tanguy (1956, p. 29), a Nantes —no mal índice de la Francia importadora de lana española y reexportadota de la misma a otros centros - en fechas inmediatamente posteriores a las de nuestro estudio, concretamente en las judicaturas de 1554 a 1559, llegaron 4.674 sacas, lo que equivale a 1.170 por año, y según Azaola (1976, p. 792) podrían llegar a las 2.000. 
TABLA 2

LAS IMPORTACIONES, 1544-1550

\begin{tabular}{|l|r|l|r|r|}
\hline & Cantidades & \multicolumn{1}{|c|}{ Unidades } & Maravedíes & $\%$ \\
\hline Lienzos & 20.810 & fardeles y paquetes & 200.516 .832 & 71,56 \\
\hline Cañamazos & 42 & fardeles & 508.788 & 0,18 \\
\hline Seda & 4 & fardeles & 712.332 & 0,25 \\
\hline Paños & 10 & fardeles & 390.490 & 0,14 \\
\hline Pastel & 22.851 & balas & 63.189 .250 & 22,6 \\
\hline Papel & 3.381 & balas & 8.686 .796 & 3,10 \\
\hline Pescado & $24 / 4$ & quintales & 61.779 & 0,02 \\
\hline Vino* & (varias) & toneles y barricas & 476.500 & 0,17 \\
\hline Libros** & 206 & balas & 5.277 .720 & 1,88 \\
\hline Varios*** & & & $\mathbf{2 8 0 . 1 9 9 . 1 4 2}$ & $\mathbf{1 0 0}$ \\
\hline Total & & & 378.655 & 0,13 \\
\hline
\end{tabular}

* 119 toneles y 2 barricas más otra cantidad indeterminada por valor de 238.250 mrs.; se evalúa el total como mínimo en el doble de esa cantidad.

** Su valor se estima, a falta de información adecuada, en el décuplo del papel.

*** Incluidos 37 cueros, una caja de naipes, otra se menaje y estaño.

cien), y cerca de 3.400 balas de papel (3 por cien), también embarcadas en el puerto del Garona. Las tres mercancías comprenden más del 97 por cien del valor monetario de las importaciones ${ }^{42}$, tratándose además de bienes finales industriales, lencería y papel, o intermedios, el pastel, intensivos en trabajo y con valores añadidos altos y medios, y derivadamente precios también altos. La naturaleza económica de los bienes importados es la opuesta a la de los exportados, lo cual tendrá evidentes efectos directos sobre la «balanza comercial».

El balance entre exportaciones e importaciones es clara y abultadamente negativo, pues arroja un saldo deficitario enorme, de 255.414.612 maravedíes en términos absolutos ${ }^{43}$. En términos relativos, el ratio entre importaciones y exportaciones es de 11:1 y la tasa de cobertura del 8,85 por cien ${ }^{44}$.

42 El alto grado de concentración del valor de los flujos comerciales en determinadas part idas hace que el potencial sesgo de nuestras estimaciones quede difuminado, en el sentido de que los órdenes de magnitud apenas variarían con cualquier otra estimación.

43 Hablamos debalance o entrecomillamos sistemáticamente «balanza comercial» a sabiendas de que en rigor no se trata de un saldo de balanza sino en sentido laxo y analógico, cuyo o rden de magnitud apunta indiciariamente en dirección avalada por toda la litertura conocida del comercio castellano.

${ }^{44}$ Casi el doble de la estimada por Priotti (2004, p. 75), en torno a 4,5 por cien, como consecuencia de utilizar precios de venta en Bilbao, que incorporan beneficios y consecuentemente 
Déficit tan exorbitante podía, sin embargo, verse equilibrado de producirse o bien superávits en los intercambios que realizan con otros países los comerciantes que operan con Francia o bien saldos positivos en otros rubros de la «balanza de pagos», concretamente en la de servicios de transporte, fletes, o en la de transferencias y capitales. Sin embargo, ninguna de estas dos posibilidades se realiza en la práctica.

Por lo que a la primera se refiere, ya se ha hecho notar que la inmensa mayoría de los comerciantes que operan con Francia lo hacen sólo y de forma pre fe rente con Francia, consecuencia probablemente de un alto grado de especialización comercial, y sólo una minoría, exactamente nueve de veinticuatro, lo hacen también con Flandes o Inglaterra. Ahora bien, los informes de estos comerciantes no avalan la suposición de que el déficit con Francia pudiese ser compensado con los movimientos comerciales en las demás direcciones, dado que el saldo de sus operaciones con Flandes es asimismo muy deficitario y con Inglaterra apenas si alcanza, y no siempre, un pequeño superávit, absolutamente insuficiente para enjugar el déficit francés.

En cuanto a la segunda posibilidad, sabido es que una de las actividades económicas de las provincias marítimas del País Vasco en general y de Bilbao en particular era el transporte naval. Las ganancias proporcionadas por la prestación de este servicio podrían eventualmente subsanar alguna parte del déficit de la balanza de mercancías, pero tal supuesto resulta poco realista para las relaciones comerciales hispano-franceses del momento. En realidad, esta partida también debía de contribuir negativamente al saldo de la balanza de pagos. La información disponible así lo atestigua. En las relaciones de mercaderes no aparecen ingresos por este concepto, salvo en algún caso en que al oficio de mercader se añade el de maestre o naviero, parte de las exportaciones se embarcan en navíos franceses y, desde luego, las importaciones de lienzos de Bretaña se realizan mayoritariamente en naves bretonas. Así, por ejemplo, Diego Pérez de Fuica y su socio Juan Martínez de Recalde arman un barco en 1544 para un viaje a Nantes, lo que les proporcionó en concepto de flete un ingreso de 46.228 maravedíes. Pero otros, como Ochoa de Arrieta y Johan de Mounier, empleaban naves francesas en sus exportaciones. Del total de 50 naos llegadas a Bilbao desde Nantes durante la judicatura de 1545 a 1546 solamente 18 corresponden a patrones con apellidos de origen castellano o vasco - entre estos últimos cabe que hubiese algún francés-y el resto son indubitablemente franceses, fundamentalmente bretones. Desde Nantes ha podido observarse que sus comerciantes mostraban una indudable preferencia por los barcos franceses, que eran de elevado porte, cargaban en los retornos y mostraban un

sobrevaloran las importaciones respecto a las exportaciones. Lo contrario ocurre con la estimación de Azaola (1976, pp. 791-792), más alta, 18 por cien, con exportaciones relativamente sobrevaloradas al utilizar precios de Nantes, aunque en rigor esta estimación no debe compararse con la nuestra por tratarse solamente del comercio de Nantes, en el que no figuran lienzos de otra procedencia que no sea Nantes ni pastel ni papel que transitan por Burdeos. 
mayor grado de especialización, mientras que los españoles, pequeños, hasta el punto de que podían ser empleados indistintamente en la pesca y el transporte, se conformaban con la exportación de frutas y algo de hierro y acero, volviendo de vacío o con unos cargamentos de escaso valor, como vino, pescado y otros alimentos ${ }^{45}$. La flota vasca como la cantábrica en general, debía de emplearse más a fondo en el comercio con Flandes e Inglaterra o en el cabotaje peninsular y la pesca que en el comercio con Francia. Así, sabemos que unos años antes, en 1534 concretamente, la flota mercante guipuzcoana apenas se dirigía al país vecino, ni el 1 por cien en términos de tonelaje ${ }^{46}$, y que las lanas embarcadas en Santander desde 1545 hasta 1551 fueron transportadas en naves españolas, casi dos tercios santanderinas y el resto vascas, del mismo modo que hacían los Salamanca en sus envíos particulares ${ }^{47}$.

La documentación en modo alguno ofrece información traducible en flujos de rentas del trabajo, de inversión, transferencias corrientes o de capital, pero sí de los movimientos de dinero, como pagos al exterior de las importaciones recibidas, que unas veces, muy ocasionales, se realizan en forma de especies, otras por medio de obligaciones, también minoritarias, y sobre todo por medio de letras de cambio, bien a la vista, las menos, bien de plaza a plaza, algo más numerosas, y de feria a feria, entre Lyon y Medina del Campo o Villalón, la inmensa mayoría. Con todo, según nuestros cálculos, muy provisionales ${ }^{48}$, la financiación de las importaciones mediante estas formas de pago sería incompleta, cosa que en buena lógica contable habría de llevarse a cabo. Por otras vías o por otros medios o por otros circuitos comerciales habrían de cuadrarse las cuentas exteriores castellanas. A fin de cuentas, el circuito francés y la vía de Bilbao no eran sino parte de una red comercial más amplia y compleja.

Esta composición del comercio y el saldo de la «balanza comercial» apuntan en una dirección que quedará más realzada tras el estudio microeconómico de este comercio, de sus comerciantes y sus facturaciones, y de lo que de ello se deduce para especificar la naturaleza y alcance de sus negocios.

45 Azaola (1976, p. 788), asegura que la proporción media de los buques españoles en el comercio con Nantes entre 1549 y 1564 oscila entre el 9 y 15 por cien, parca participación a la que hay que añadir el hecho de que «los barcos españoles... vienen ante todo a descargar, sin preocuparse de obtener, o sin poder conseguir, un flete de vuelta». Véase también Priotti (2004, p. 68) y Tanguy (1956, p. 61), que matiza estas apreciaciones.

${ }^{46}$ Fernández de Pinedo (1983, p. 105).

47 Véase respectivamente Maza Solano (1957, pp. 343-344) y Uriarte (1999, pp. 168-171), quien advierte que en el transporte de otras mercancías podían recurrir a barcos extranjeros.

${ }^{48}$ El volumen de estos movimientos sería de unos 12,5 millones de maravedíes, cifra muy, repetimos, muy provisional, que por mucho que se alzara en modo alguno lograría cumplir con los pagos de las importaciones. 


\section{LOS COMERCIANTES: VOLUMEN Y ALCANCE DE SUS NEGOCIOS}

El valor de las importaciones y exportaciones que mueven los comerciantes revela un volumen medio de facturación de algo más de 3,5 millones de maravedíes anuales, que, en comparación con el de los castellanos, resulta ser más bien modesto ${ }^{49}$. La jerarquía de los comerciantes bilbaínos y algunos extranjeros avecindados en la villa está encabezada por Juan de Venero y Martín Sáez de Anuncibay, cuyas operaciones sobrepasan los 8 millones de maravedíes anuales, y la cierran Rodrigo de Salvatierra, que en tres años factura una media inferior al medio millón de maravedíes, y Juan de Berdeci, cuya actividad parece ser más bien anecdótica. Excepto Juan de Luxeri, todos son importadores en mayor medida que exportadores, y algunos solamente importadores, lo cual expresa muy sintéticamente el alcance de los negocios de estas firmas comerciales.

A grandes rasgos, el comportamiento de estos mercaderes responde a los modelos siguientes. En primer lugar, están los mercaderes modestos que realizan un intercambio fundamentalmente bilateral de lienzos por hierro y acero, en el que logran casi equilibrar el valor de las importaciones con el de las exportaciones. Además del citado Rodrigo de Salvatierra, figuran en este grupo Juan de Jarnigan, Martín de Güemes y Ochoa de Arrieta. Otro grupo de mercaderes facturan cantidades sensiblemente mayores, pero están lejos de conseguir que el valor de las exportaciones de hierro y acero, cuyas cantidades eran verdaderamente importantes, alcanzara el de las importaciones de lienzos. A diferencia de los anteriores, éstos participaban abiertamente en operaciones de cambio, tomando dinero en Castilla para las ferias de Lyon y consiguiendo además una considerable ganancia con las diferencias de los tipos de cambio. Diego Pérez de Fuica, por sí mismo y en compañía de Juan Martínez de Recalde ${ }^{50}$, era uno de los más destacados de este grupo, además de Alonso de Vitoria y el mencionado Juan de Luxeri.

Un tercer modelo lo forman unos pocos comerciantes que eran meros importadores. Entre ellos destacan dos nanteses afincados en Bilbao, Jaques Bernat y Juan de Aranda, éste de origen claramente castellano, además de Ortuño de Baquio, Bartolomé de Catelinaga, Pedro Sáez de Arexmendi - que comercia mucho más con Flandes e Inglaterra que con Francia-, Martín de Arbolancha Arana - que dice no haber comerciado nunca sino con Francia-, Pedro Ibáñez de Novia — que trabaja con Juan de Lerma y los herederos de Gregorio de Lerma, vecinos de Burgos, en la importación de pastel y algunos lienzos- y, finalmente, el ya citado Juan de

49 En puridad, los datos que ofrecen las relaciones de mercaderes que manejamos no son estrictamente comparables con los que recoge Casado (1997, pp. 316-322); éstos se refieren a las ventas de algunas compañías mercantiles castellanas, por lo que entendemos que las diferencias debían de ser realmente mucho mayores.

${ }_{50} \mathrm{El} \mathrm{mismo} \mathrm{armador} \mathrm{seguramente} \mathrm{que} \mathrm{años} \mathrm{después} \mathrm{gozaba} \mathrm{de} \mathrm{la} \mathrm{confianza} \mathrm{de} \mathrm{Felipe} \mathrm{II}$ como correo oficial con Flandes vía Nantes. Lapeyre (1955, p. 170). 
TABLA 3

LOS COMERCIANTES Y SU VOLUMEN DE FACTURACIÓN, 1544-1550

(en maravedíes)

\begin{tabular}{|c|c|c|c|c|c|}
\hline Mercaderes & Exportacio. & Importaciones & Total & Años & Media \\
\hline Juan de Venero & 140.848 & 21.379 .098 & 21.519 .946 & 2 & 10.759 .973 \\
\hline Martín de Anuncibay & 1.136 .450 & 55.339 .852 & 56.476 .302 & 7 & 8.068 .043 \\
\hline Ochoa Lanier & 1.125 .391 & 43.847 .200 & 44.972 .591 & 6 & 7.495 .432 \\
\hline Bartolomé de Miranda & 1.950 .831 & 25.300 .000 & 27.250 .831 & 4 & 6.812 .708 \\
\hline Martín de Guinea & 1.177 .733 & 12.191 .140 & 13.368 .873 & 2 & 6.684 .437 \\
\hline Juan de Aranda & 0 & 6.062 .800 & 6.062 .800 & 1 & 6.062 .800 \\
\hline Bartolomé de Catelinaga & 0 & 19.890 .400 & 19.890 .400 & 4 & 4.972 .600 \\
\hline Pedro Ibáñez de Novia & 0 & 24.125 .275 & 24.125 .275 & 5 & 4.825 .055 \\
\hline Pedro Amendux & 1.951 .776 & 16.422 .366 & 18.374 .142 & 4 & 4.593 .536 \\
\hline Jaques Bernat & 0 & 7.295 .600 & 7.295 .600 & 2 & 3.647 .800 \\
\hline Juan Jarnigan & 1.442 .607 & 1.867 .600 & 3.310 .207 & 1 & 3.310 .207 \\
\hline Ochoa de Larrea & 232.280 & 6.195 .886 & 6.428 .166 & 2 & 3.214 .083 \\
\hline Ochoa de Arrieta & 2.097 .301 & 3.026 .800 & 5.124 .101 & 2 & 2.562 .050 \\
\hline Diego Pérez de Fuica & 4.773 .812 & 9.616 .556 & 14.390 .368 & 7 & 2.055 .767 \\
\hline Juan Lemonier & 861.974 & 1.026 .618 & 1.888 .592 & 1 & 1.888 .592 \\
\hline Ortuño de Baquio & 0 & 8.113 .875 & 8.113 .875 & 6 & 1.352 .313 \\
\hline Juan de Luxeri & 1.999 .328 & 1.663 .578 & 3.662 .906 & 3 & 1.220 .969 \\
\hline Martín de Salvatierra & 3.262 .312 & 3.468 .400 & 6.730 .712 & 6 & 1.121 .785 \\
\hline Alonso de Vitoria & 1.075 .175 & 5.965 .022 & 7.040 .197 & 7 & 1.005 .742 \\
\hline Martín de Arbolancha Arana & 0 & 3.982 .075 & 3.982 .075 & 5 & 796.415 \\
\hline Pedro Sáez de Arexmendi & 0 & 712.332 & 712.332 & 1 & 712.332 \\
\hline Martín de Güemes & 1.176 .094 & 1.201 .124 & 2.377 .218 & 4 & 594.305 \\
\hline Rodrigo de Salvatierra & 380.618 & 1.483 .945 & 1.864 .563 & 3 & 621.521 \\
\hline Juan de Berdeci & 0 & 21.600 & 21.600 & 1 & 21.600 \\
\hline Total & 24.784 .530 & 280.199 .142 & 304.983 .672 & 3,58 & 85.190 .970 \\
\hline
\end{tabular}

Venero, que hacía dos años había regresado a Bilbao procedente de Burdeos. Allí había trabajado para Diego de Bernuy, de quien es intermediario en la importación de pastel, aunque también negocia por cuenta pro- 
pia una pequeña operación de vino bordelés por sardina arencada de Galicia. En realidad, el hecho de facturar grandes o pequeñas cantidades, pero sólo en la importación y por cuenta exclusivamente de un mercader, o bien francés o bien castellano, hace pensar que se trata en realidad de factores o comisionistas antes que mercaderes propiamente dichos.

En cuarto y último lugar debemos destacar a los mercaderes que movían el mayor volumen de negocio mediante las importaciones masivas de lienzos por cuenta de diversos mercaderes castellanos, aunque también emprendían operaciones por cuenta propia de manera personal o en compañía de algún socio. El más destacado de todos era sin duda Martín de Anuncibay, de quien sabemos que fue durante mucho tiempo factor de los Salamanca ${ }^{51}$ y que trabajó desde 1544 hasta 1550 en compañía de otros mercaderes, citados en las relaciones, y también por cuenta de otros mercaderes vascos y castellanos ${ }^{52}$. El siguiente en la lista es Ochoa Lanier, que exporta hierro e importa lencería de Bretaña entre los años 1545-1550, el hierro por cuenta propia y la lencería por la de Vítores Ruiz y Francisco de Izunza, y que en las averías de Nantes de 1545-1546 consta haber sido el principal importador con nada menos que el 18 por cien de los fardeles procedentes del puerto francés ${ }^{53}$. A continuación destaca Bartolomé de Miranda, que comercia por cuenta propia, ajena y en compañía, de modo preferente con Nantes —donde otros Miranda acabaron arraigando-, aunque también importa de Flandes algunas mercaderías. La mayor parte de sus importaciones por cuenta propia son vendidas en las ferias de Castilla y sólo una décima parte aproximadamente en Bilbao. De aquí estuvo ausente unos años, lo cual no impidió que siguiera negociando en la villa por medio de terceros ${ }^{54}$. Por último, debemos mencionar a Martín de Guinea ${ }^{55}$, que trabajó en los años 1548 y 1549 en compañía de Martín Ruiz de

51 Uriarte Melo (1999, p. 53) y (2006).

52 Trabajó en compañía de Juan de Aberasturi y de Ochoa Lanier, así como por cuenta de Juan de Ugalde, estante en Medina del Campo, Juan de Anuncibay, cuyo parentesco desconocemos, y los mercaderes castellanos Alonso, Miguel y García de Salamanca, Diego de Villadiego, Francisco de Lantadilla, su hijo Martín de Anuncibay, que comerciaba en compañía de Juan Calvete, Gonzalo Tamayo, Diego y Álvaro González de Medina y Bernaldino de Miranda, así como también con Juan de Oldabarri, Joldán Díaz de Domaiquia y Francisco de Cucho. Esto solamente en el comercio con Francia, pues también desempeñó alguna actividad en Flandes.

53 Según nuestros datos, la mayor parte había sido remitida por Francisco de Santo Domingo, Francisco de la Presa y Andrés Ruiz. De hecho, en 1551 es correspondiente en Bilbao de la compañía de Simón Ruiz y Juan de Orbea, al tiempo que Andrés Ruiz lo es en Nantes. Sobre esto último, véase Lapeyre (1955, p. 61).

54 Por cuenta propia y en compañía de María de Miranda exporta algunas sacas de lana compradas en Tierra de Campos y Ávila con destino a Nantes, pero nada de hierro. También adquiere terciopelos de Toledo, aunque no especifica su destino. Por supuesto toma a cambio en Castilla. A pesar de que ofrece datos desde 1544, faltan algunos años total o parcialmente. Las mercaderías por cuenta ajena son recibidas en su ausencia durante parte de 1545, todo 1546 y parte de 1548 por Juan de Zornoza y durante una parte de este último año, más los de 1549 y 1550, por Martín de Bertendona.

$55 \mathrm{Su}$ información puede que sea incompleta, pues falta la cabecera de su relación. 
Salvatierra - probablemente el mismo citado anteriormente- en negocios de importación de lienzos y exportación de hierro y acero a Nantes, de donde importa asimismo varias partidas de libros por cuenta de mercaderes de Burgos, Medina del Campo, Medina de Rioseco, Villalón y Salamanca. Además, es uno de los pocos que también opera con Flandes.

Algunos de los apellidos aquí reseñados corresponden a familias de origen castellano que se habían asentado desde hacía tiempo en los grandes puertos franceses, muy particularmente en Nantes, donde seguían manteniendo fuertes vínculos personales, hasta el punto de conseguir la naturalización ${ }^{56}$. La mayoría de los comerciantes bilbaínos había establecido estrechos lazos profesionales con los principales comerciantes de Burgos, Medina del Campo y Nantes, a quienes servían en calidad de huéspedes, correspondientes o comisionistas. En cualquier caso, no es ocioso recordar que bastantes de estos mercaderes, y otros que aparecen en la documentación operando en dirección a Flandes o Inglaterra, ocuparon los más importantes cargos del Ayuntamiento de la villa y las más altas magistraturas del Consulado ${ }^{57}$.

Las averías de Nantes dan testimonio de la participación relativa de cada comerciante en el comercio en términos de volumen físico - fardeles remitidos-, revelando un alto grado de concentración de los negocios en manos de muy pocos mercaderes que merezcan tal nombre. La tabla 4 muestra que los 10.161 fardeles que remitieron los cargadores del puerto francés a Bilbao en la judicatura de 1545-1546 fueron recibidos y gestionados por 58 personas o huéspedes, de los cuales sólo diez (el 17 por cien) acaparaban el 75 por cien de la carga total con 766 fardeles de promedio por agente, y dieciocho (el 31 por cien) el 91 por cien de la carga con una media de 515 fardeles. Las pequeñas, cuando no insignificantes cantidades que recibieron los demás agentes - exactamente 39, que representan el 67 por cien pero mueven unos 22 fardeles de promedio- permiten conjeturar que no se trata de mercaderes propiamente dichos, sino de pequeños, muy pequeños comerciantes, cuando no tenderos y particulares, que ocasionalmente operaban en el comercio, como parece que siguió siendo la tónica en épocas posteriores ${ }^{58}$. Estos datos revelan que los agentes comerciales que realmente contaban en Bilbao no eran muchos y que, además, los negocios estaban fuertemente concentrados. Esta misma concentración, aunque algo

${ }^{56}$ Los Aranda, Miranda y Vitoria habían arraigado tiempo atrás en Nantes. Tanguy (1956, p. 76), Casado (1995) y Priotti (1995, p. 271) y (2004).

${ }^{57}$ Los Anuncibay, Catelinaga, Fuica, Larrea, Arbolancha, Arexmendi y Güemes fueron, algunos más de una vez, priores y cónsules del Consulado. Ibáñez de Nobia fue regidor y fiel del Ayuntamiento y Pérez de Fuica regidor perpetuo y activo protagonista de las reformas de las o rdenanzas de 1544, pieza in stitucional señera en el proceso de oligarquización del poder local. Todo ello pone de manifiesto que nos hallamos ante lo más granado de las fuerzas políticas y económicas de la villa. Cfr. Guiard [1913 (1972]) p. 634]; Labayru [1900 (1968), p. 245]; Pérez (2005).

${ }^{58}$ Zabala (1999, p. 459). 
ENTRE CASTILLA Y FRANCIA: COMERCIO Y COMERCIANTES EN BILBAO A MEDIADOS...

TABLA 4

LA CONCENTRACIÓN DE LOS NEGOCIOS, 1544-1550

\begin{tabular}{|c|c|c|c|c|c|c|c|c|}
\hline Fardeles & \multicolumn{5}{|c|}{ Huéspedes } & \multicolumn{5}{c|}{ Cargadores } \\
\hline & Núm. & $\%$ & Fardeles & $\%$ & Núm. & $\%$ & Fardeles & $\%$ \\
\hline$>1.000$ & 2 & 3,45 & $3.432,25$ & 33,80 & 1 & 1,20 & $1.603,00$ & 15,80 \\
\hline $500-1.000$ & 4 & 6,90 & $2.568,00$ & 25,27 & 1 & 1,20 & 778,50 & 7,66 \\
\hline $250-500$ & 4 & 6,90 & $1.663,25$ & 16,37 & 15 & 18,07 & $5.290,00$ & 52,06 \\
\hline $100-250$ & 8 & 13,79 & $1.606,25$ & 15,81 & 7 & 8,43 & $1.248,75$ & 12,29 \\
\hline $50-100$ & 4 & 6,90 & 323,00 & 3,18 & 8 & 9,64 & 645,00 & 6,35 \\
\hline $25-50$ & 7 & 12,07 & 255,00 & 2,51 & 7 & 8,43 & 236,50 & 2,33 \\
\hline$<25$ & 29 & 50,00 & 313,25 & 3,08 & 44 & 53,01 & 359,25 & 3,54 \\
\hline Total* & 58 & 100,00 & $10.161,00$ & 100,00 & 83 & 100,00 & $10.161,00$ & 100 \\
\hline Índice de Gini $^{-9}$ & \multicolumn{7}{|c|}{$\mathbf{0 , 7 7}$} & \multicolumn{5}{|c|}{$\mathbf{0 , 7 2}$} \\
\hline
\end{tabular}

* El total indicado es ligeramente inferior (0,22 por cien, diferencia despreciable) al que se deduce de las sumas de los totales de cada nao que aparecen en las respectivas averías.

menos intensa, como lo revela de modo sintético el índice de Gini, se advierte del lado de los cargadores de Nantes: 17 de ellos (20 por cien) remiten el 75 por cien de los fardeles, 451 cada uno, y 39 (el 47 por cien) el 97 por cien del total con un promedio de 251 . Los 44 cargadores restantes (53 por cien) expiden un número de fardeles comparativamente insignificantes, tanto en términos generales —no llega al 4 por cien del total- como en promedio sólo ocho fardeles por agente. Esta concentración ¿es algo ocasional de esta judicatura o puede extenderse al resto de los años? La ausencia de información similar para esos años impide dar una respuesta categórica a la pregunta, pero la comparación entre los datos de las averías y los de las rela ciones de mercaderes apunta una respuesta positiva. Tal y como se ha adelantado, no todos los comerciantes que figuran en las relaciones de merca deres de 1550 aparecen en las averías de cinco años antes, porque algunos todavía no estaban en Bilbao o habían muerto. Los que figuran en ambos documentos, en número de trece, recibieron el 57 por cien de la carga, cifra que, como se ha argumentado, podría elevarse al 62 por cien. Similar grado de concentración de los negocios se proyecta hasta los destinatarios finales de la cadena de comercialización, los mercaderes que en Castilla reciben los géneros remitidos desde Bilbao ${ }^{59}$.

59 Bartolomé de Catelinaga remite a siete mercaderes de Castilla y otros dos inidentificables 2.132 fardeles de lienzos de Bretaña: 931 son recibidos por Blas de Medina y 464 por Fernando 
Ante los escenarios descritos, directamente colegidos de las nuevas fuentes, cabe preguntarse si estamos ante mercaderes en el sentido estricto y fuerte del término o más bien frente a un cuadro de factores o meros comisionistas. La respuesta a la pregunta debe matizarse en función de las direcciones del comercio y el grado de control comercial que en cada una de ellas ejercen estos protagonistas. La documentación, como se ha adelantado, permite desagregar las operaciones llevadas a cabo por los agentes comerciales entre negocios por cuenta propia, en compañía con otros agentes o por cuenta ajena. El cuadro 5 plasma esta situación, evidenciando que en el renglón de las exportaciones el grado de control comercial directo ejercido por los bilbaínos, medido por el volumen de negocio por cuenta propia, es mucho más alto que en el de las importaciones, nada menos que el 59 por cien frente al 9 por cien y el 94 y el 15 por cien respectivamente si incluimos los negocios en compañía. La razón última de esta diferencia radica en el control practicado sobre las exportaciones de productos siderúrgicos, cuyo peso en las exportaciones totales es mayoritario. Si sumamos el comercio de hierro y acero por cuenta propia con el asociado alcanzamos valores del 98 por cien. La suma no es del todo caprichosa, pues una buena partida de estos negocios asociados de los bilbaínos era efectivamente realizada en compañía con otros negociantes bilbaínos o vascos. Nuestros comerciantes ejercían también un elevado control sobre otras mercancías: absoluto sobre la grasa de ballena, producto calificable también de doméstico en la medida que era fruto de capturas propias ${ }^{60}$, y alto sobre las especias, producto de reexportación, aunque la participación de estas mercancías en el valor total de las exportaciones era baja ${ }^{61}$. Por tanto, se pone de manifiesto una vez más que la clave del comercio bilbaíno del lado de las exportaciones residía en un producto doméstico, el hierro, y en el control, muy alto, que sus comerciantes ejercían sobre él. En modo alguno sobre las exportaciones de lana, que, además de escasas -8 por cien del valor de las exportaciones totales- sólo eran controladas en poco más de su tercera parte ${ }^{62}$.

La imagen de las importaciones es exactamente la inversa. De las tres grandes rúbricas del comercio de importación, lienzos, pastel y papel, la

de Frías, lo que equivale al 65 por cien del total, mientras que los otros siete mercaderes restantes recibieron cada uno 100 fardeles.

${ }_{60}$ Barkham (1990).

${ }^{61}$ A la vista de estos datos, el papel de Bilbao en la redistribución de coloniales desde la península ibérica hacia el norte de Europa a mediados del siglo XVI parece ser todavía muy modesto.

${ }_{62}$ Sobre el control del comercio global de la villa, $c f r$. Bilbao (2003a, pp. 246-254). Las cifras deducidas de nuestra fuente documental sobre el control del comercio con Francia son bastante coherentes con las de tres muestras de «afletamientos» salvados de la riada de 1593 que datan de mediados del siglo XVI y los años 1564 y 1569, y se refieren al comercio bilbaíno con Europa en general: de 1.176 sacas de lana sólo el 8 por cien corresponden a bilbaínos, pero de 250 quintales de hierro, la cifra sube hasta el 66 por cien, según se deduce de Guiard [1913 (1972), pp. 69-82]. 
tasa de control por parte de los bilbaínos es corta: 12 por cien en la lencería y nada en las otras rúbricas, no valiendo ya sumar el negocio en compañía al de por cuenta propia, pues las sociedades eran en estos casos mayoritariamente con franceses o castellanos. El control agregado por parte de los bilbaínos de todo este tráfico import-export alcanzaba sólo al 13 por cien, y si además les atribuimos todo lo negociado por ellos en asociación con otros comerciantes - supuesto no plenamente realista- se llegaría al 21 por cien. El resto, el 80 por 100 como mínimo, era cuestión de castellanos y franceses. Resumiendo, los comerciantes bilbaínos ejercen un control muy elevado, casi total, en la principal partida de exportación, los productos siderúrgicos, y bastante menos, entre el 12 y el 19 por cien como máximo, sobre las importaciones de lienzos, pero en conjunto y como mucho sólo controlan el 20 por cien del tráfico de mercancías del circuito comercial franco-español que pasa por Bilbao.

TABLA 5

EL CONTROL COMERCIAL, 1544-1550

(en tantos por cien del valor de cada rúbrica)

\begin{tabular}{|l|c|c|c|}
\hline \multicolumn{1}{|c|}{ Productos } & \multicolumn{2}{c|}{ Por cuenta propia } & Por cuenta ajena \\
\hline & Personal & En compañía & \\
\hline Lienzos & 12,42 & 6,26 & 81,32 \\
\hline Pastel & 0,00 & 0,00 & 100,00 \\
\hline Papel & 0,00 & 4,92 & 95,08 \\
\hline Pescado & 80,82 & 19,18 & 0,00 \\
\hline Libros & 0,00 & 47,09 & 52,91 \\
\hline Varios & 74,88 & 8,92 & 16,20 \\
\hline Total Importaciones & $\mathbf{9 , 4 3}$ & $\mathbf{5 , 6 6}$ & $\mathbf{8 4 , 9 1}$ \\
\hline Hierro y Acero & 60,01 & 37,74 & 2,25 \\
\hline Lana & 40,06 & 59,94 & 0,00 \\
\hline Especias & 27,30 & 38,82 & 33,88 \\
\hline Grasa de ballena & 100,00 & 0,00 & 0,00 \\
\hline Sombreros & 100,00 & 0,00 & 0,00 \\
\hline Varios & 35,86 & 4,68 & 59,46 \\
\hline Total Exportaciones & $\mathbf{5 8 , 8 7}$ & $\mathbf{3 5 , 3 6}$ & $\mathbf{5 , 7 7}$ \\
\hline TOTAL Import-Export & $\mathbf{1 3 , 4 5}$ & $\mathbf{8 , 0 7}$ & $\mathbf{7 8 , 4 8}$ \\
\hline
\end{tabular}


La combinación de un fuerte saldo negativo de la «balanza comercial» con un grado de control mucho menor en las importaciones que en las exportaciones implica necesariamente que el grueso del déficit debía recaer sobre la parte del comercio por cuenta ajena que declaran los factores o encomenderos de mercaderes castellanos o extranjeros: nada menos que el 85 por cien, lo cual no deja de ser un aspecto relevante de la naturaleza y alcance del comercio bilbaíno. En cambio, a la fracción del comercio ejercido por los comerciantes bilbaínos personalmente y en compañía de socios de la villa y comerciantes castellanos o extranjeros sólo se le puede imputar una pequeña parte de este déficit. Dicho de otro modo, todas las balanzas comerciales son deficitarias, pero el grado relativo de cobertura de las importaciones por parte de las exportaciones es bien distinto según se trate de comercio por cuenta propia, personal o en compañía, o por cuenta ajena: el 55 por cien en los dos primeros casos y solamente el ¡0,6 por cien! en el segundo. Todo esto apunta hacia los verdaderos agentes comerciales que han de hacer frente al monumental déficit observado.

TABLA 6

LA «BALANZA COMERCIAL»

SEGÚN LA NATURALEZA DE LA EMPRESA MERCANTIL, 1544-1550 (en maravedíes)

\begin{tabular}{|l|c|c|c|c|}
\hline \multicolumn{1}{|c|}{ Tipo de empresa } & Exportaciones & Importaciones & \multicolumn{1}{c|}{ Saldo } & Cobertura (\%) \\
\hline Por cuenta propia & 14.590 .963 & 26.430 .910 & -11.839 .947 & 55,20 \\
\hline En compañía & 8.763 .045 & 15.856 .656 & -7.093 .611 & 55,26 \\
\hline Por cuenta ajena & 1.430 .522 & 237.911 .576 & -236.481 .054 & 0,60 \\
\hline Total & $\mathbf{2 4 . 7 8 4 . 5 3 0}$ & $\mathbf{2 8 0 . 1 9 9 . 1 4 2}$ & $\mathbf{- 2 5 5 . 4 1 4 . 6 1 2}$ & $\mathbf{8 , 8 5}$ \\
\hline
\end{tabular}

La naturaleza del comercio realizado a través del puerto de Bilbao con Francia, tal y como se desprende de las observaciones realizadas, puede definirse en términos de comercio de tránsito. Bilbao no sólo era en este circuito un puerto esencialmente de importación sino un puerto de tránsito, un entrepôt, donde las mercancías recibidas apenas eran retenidas y desde donde se distribuían por los distintos mercados peninsulares. Era más un puerto de importación de productos franceses para el mercado español que un puerto exportador de productos españoles a Francia. Los datos son contundentes: la proporción de las importaciones en el comercio total era del ¡92 por cien! Además, las importaciones retenidas en su plaza eran relativamente pocas en comparación con el volumen total de importación. De hecho, la capacidad de absorción del mercado local, bilbaíno o vasco, y la venta in situ para otros mercados españoles de las importaciones francesas que se descargaban en su puerto era reducida: en ningún caso superior al 
20 por cien de los lienzos, y mucho menos en otras mercancías ${ }^{63}$. El resto se recibía en tránsito camino de Castilla, Rioja y Navarra, o por cabotaje hacia otros puertos de la península y eventualmente, mediando Sevilla, a América. Podría suponerse que sobre los lienzos retenidos y vendidos en la plaza de Bilbao los comerciantes ejercerían un control pleno y que, en consecuencia, estaban especializados en el abastecimiento del mercado urbano y su área de influencia. La cifra agregada del 20 por cien resulta en parte engañosa, pues más de la mitad de los lienzos que los bilbaínos importan por su cuenta es efectivamente retenida y vendida en Bilbao (1.119 bultos de 2.094), sin embargo sólo el 16 por cien de los que operan por cuenta ajena (2.747 de 16.906). Ello prueba que las operaciones comerciales que los bilbaínos hacen por cuenta propia están orientadas mayoritariamente a abastecer el mercado local, pero también que el grueso del abastecimiento local, el 71 por cien, se hace con mercancías ajenas que no controlan directamente, con lienzos, en suma, cuyo control recae en última instancia sobre castellanos y franceses ${ }^{64}$.

El comercio en sentido pleno, con capacidad para organizar y controlar todo el proceso comercial, desde la inversión inicial para la compra de mercaderías hasta la venta final, era cosa propia más bien de las grandes casas y compañías comerciales castellanas y francesas que de los comerciantes bilbaínos. El control pleno del comercio no significa implicarse directamente en todas las fases del proceso mercantil. El espectro de actividades que entonces componía este proceso era múltiple y variado y la división técnica del trabajo comercial compleja. Parte de estas actividades eran exter nalizadas, subcontratadas por las grandes casas comerciales a agentes dis-

${ }_{63}$ En efecto, la proporción en otras partidas parece ser aún menor. Alonso de Vitoria, por ejemplo, vende en Bilbao el 6,5 por cien del pastel que importa; Ochoa de Larrea, el 1,3 por cien del papel, y Ortuño de Baquio, 40 balas de papel y nai pes de las 3.081 que importa, lo que representa el mismo 1,3 por cien. Los Aranda, Arbolancha, Ibáñez y Miranda remiten toda la lencería negociada por cuenta ajena a Castilla. De las mercancías enviadas a Castilla los mercaderes intermediarios rinden cuentas ante el juez de comisión sólo de cantidades nunca de valores, las de valor las tendrían que rendir en su caso los consignatarios, como propietarios de las mercancías que eran.

${ }^{64}$ La re presentación de la plaza de Bilbao como punto de venta de las importaciones europeas y mercado de abastecimiento a donde acuden los mercaderes castellanos no se corresponde, desde luego, con los años finales de $1540 \mathrm{ni}$ con los productos franceses. Los lugares de venta de estos géneros en esos años son las ciudades y pueblos de Castilla y sobre todo sus ferias, donde los bilbaínos y los factores extranjeros en Bilbao remiten las mercancías a los consignatarios castellanos, según las relaciones de mercaderes. Cuando se refiere a los años de 1560 diciendo que «...les marchands de l'intérieur de Vielle et Nouvelle-Castille sont contraints de se rendreau Pays Basque pour s'approvisionner. En déplaçant les rendez-vous des aff a i res à Bilbao les operateurs basques ont dérobé une part du contrôle du marché intérieur...», Priotti (2004, p. 122) adelanta un fenómeno que Eugenio Larruga situaba en una fecha posterior a la renovación del encabezamiento general de alcabalas, que al poner fin a la exención de las primeras ventas en las ferias de Medina del Campo provocó un desplazamiento de las operaciones a Vi zcaya y Guipúzcoa, donde la alcabala o no se pagaba o estaba fosilizada en un precio muy bajo. Este aspecto ha sido resaltado por Fernández de Pinedo (1998, p. 118). 
tintos de las mismas. Entre ellos estaban los transportistas y diferentes intermediarios, factores permanentes, comisionistas o cargadores más o menos ocasionales, que actuaban por encargo de aquéllos, percibiendo remuneraciones fijas o por servicio prestado. Éstos, a su vez, podían colaborar con otros en determinadas labores similares pero en distintos puertos, realizando economías de escala o más bien de alcance, o subcontratar a terceros faenas más secundarias, como carga, descarga y almacenamiento. Las difíciles condiciones en que se desarrollaba la actividad comercial, consecuencia de las restricciones técnicas del trasporte y las comunicaciones, escasez y asimetría de información e incertidumbre general determinaban la necesidad de una organización ajustada de dicha actividad y una estrecha colaboración a distintos niveles entre distintos agentes del comercio. La pluriactividad dentro del sector comercial era la norma entre los mercaderes, fuesen poderosos o chicos ${ }^{65}$.

La clave de la empresa comercial, y la fuente principal de acumulación de capital, estribaba en organizar y gestionar todo este complicado proceso. Los comerciantes bilbaínos con Francia estaban en aquel momento fuera de este gran juego, dependiendo en la mayor parte de sus operaciones de importación de las grandes casas comerciales para las que actuaban subordinadamente como factores o comisionistas a su servicio. A semejanza de lo que sucedía en el transporte marítimo - donde el patrón y armador, lo mismo vasco que español en general, «es a la vez propietario y transportista de la mercadería, y no lleva sino ocasionalmente mercancías por cuenta ajena» ${ }^{66}$, estando lejos, por tanto, del grado de especialización del típico naviero francés-, en el comercio se denota también una cierta falta de desarrollo, lo que permite definir al sistema mercantil de Bilbao de este momento y en este circuito como atrasado en relación con el que practicaban franceses y castellanos con sus grandes compañías. Los últimos días de estas compañías y su sistema de comercio está sin embargo próximo y los pequeños y medianos comerciantes europeos, entre ellos los bilbaínos y algunos otros castellanos diferentes a los burgaleses, contarán con oportunidades para sustituirles reorganizando el sistema de comercio ${ }^{67}$. En su favor, los comerciantes de Bilbao controlaban el ramo más importante de las exportaciones, los hierros, y realizaban operaciones por cuenta propia y en compañía en las importaciones, lo que les permitía ir acumulando capi-

${ }^{65}$ La colaboración no sólo tenía dirección horizontal, entre iguales o similares, sino una orientación también vertical y jerarquizada, entre desiguales, y ello tanto «hacia arriba» como «hacia abajo». Así, las poderosas compañías comerciales operaban no sólo por cuenta propia sino que ejercían a su vez funciones de factoría o encomienda de otras de menor cuantía. Tal es el caso de la más importante compañía de Nantes, la de Andrés Ruiz, quien actuaba de factor o encomendero de «más de 20 compañías distintas»: Azaola (1976, p. 790).

66 Azaola (1976, p. 788).

${ }_{67}$ No sin el concurso del capital financiero y humano que se irá acumulando a partir de la segunda mitad del siglo XVI. Bilbao (2003, p. 253). 
tal humano y financiero, experiencia comercial y reputación. Pero a mediados del siglo XVI no era aún llegado el momento en que habían de encarnar el dicho de época: «en poco tiempo vienen ricos e hacen a sus amos pobres» ${ }^{68}$.

Los castellanos operaban en un sistema de comercio cuyo radio de acción alcanzaba una mayor amplitud que el del mercado francés. Sus intercambios con Francia a través de Bilbao no eran sino un segmento de una red comercial mucho más amplia, de un comercio que hoy diríamos multilateral, que desbordaba el bilateral con el país vecino. En él podían ellos disponer de recursos comerciales y financieros, mercancías y capitales, con los que enjugar el déficit de la «balanza comercial» de España con Francia, pero que no aparecen, ni pueden aparecer, en las contabilidades de los mercaderes bilbaínos que operan con este país. En concreto, y sobre todo, las lanas, que mayoritariamente salen por Santander y otros puertos cántabros, permiten disponer de liquidez en las ferias flamencas para transferirla a otras ferias europeas o castellanas. Los comerciantes de Bilbao, amén de sus navieros y transportistas, cuentan con el recurso de los hierros que envían a Inglaterra y Flandes y con parte de los fletes procedentes del acarreo de la lana embarcada en los demás puertos del Cantábrico. Entre éstos venía estableciéndose una indudable competencia que daba lugar a complementariedades y especializaciones de grado muy diverso, y aunque el puerto de Bilbao era seguramente el más importante, no era el único que servía para vincular a Castilla con el norte de Europa mediante diferentes circuitos comerciales. No conviene perder esta doble perspectiva, de circuitos y puertos múltiples, pues, de lo contrario, se puede incurrir en un error metodológico irremediable para el estudio del comercio franco-español a mediados del siglo XvI. Tampoco debe dejarse de anotar que el estudio del comercio atlántico a través de Bilbao en otros circuitos, flamenco e inglés, permitirá corroborar o corregir la imagen que se desprende de las operaciones de los mercaderes bilbaínos en el comercio con Francia.

\section{CONCLUSIÓN}

La causa judicial abierta por la más alta magistratura de la Corona en 1549 con el fin de averiguar el alcance que estaba tomando la saca de mone da del reino nos ha proporcionado una documentación tan rica y fiable como provechosa a la hora de estudiar el comercio exterior de Castilla a través del puerto de Bilbao. En particular, las relaciones de mercaderes que con-

68 Angulo (2005) expone una cabal re presentación de la compleja figura del comerciante a larga distancia en la era preindustrial. En el Apéndice del mismo Angulo (2005, pp. 108-155) aparecen algunos de nuestros comerciantes, y otros más, así caracterizados por la documentación que maneja el autor: la mayoría de ellos, sólo como carg a dores y encomenderos, y los menos, como mercaderes que además practican actividades de carga y encomienda. 
signan las operaciones realizadas en los años 1544-1550, las manifestacio nes de extranjeros y las averías de Nantes nos han permitido crear una nueva base de datos más que suficientemente representativa de la estructura del comercio, el volumen de facturación de los comerciantes radicados en la villa y la naturaleza de sus empresas.

La estructura del comercio que se observa presenta unas propiedades básicas muy claras. Primero, un alto grado de concentración, por el lado de las exportaciones en los productos siderúrgicos, que representan el 78 por cien del total, y por el de las importaciones en los lienzos, que a su vez significan el 72 por cien. Segundo, un abultado déficit, dado que el valor de las importaciones es once veces mayor que el de las exportaciones, déficit que en modo alguno puede ser compensado con los ingresos procedentes del transporte marítimo, pues a este respecto se encuentra mayoritariamente en manos de navieros franceses, ni en otras direcciones, donde nuestros comerciantes operan poco y asimismo con déficit. Y, en tercer lugar, un carácter de tránsito entre Francia y España, dado que la proporción de mercancías retenidas en la plaza de Bilbao era muy pequeña en comparación con la que se internaba con destino final a las ferias de Castilla. De estos hechos se deduce que el comercio a través de Bilbao formaba parte de un entramado más amplio y complejo en el que sólo era posible alcanzar el equilibrio de la «balanza de comercio» por medio de la exportación o bien de mercancías como la lana o bien de metales preciosos - la saca de moneda a que se refiere la documentación- que necesariamente requerían el concurso de los grandes mercaderes castellanos y de otros puertos cantábricos.

El alcance de la empresa mercantil en el Bilbao de mediados del siglo XVI se revela bastante discreto, tanto en términos de volumen de negocio, pues queda lejos todavía de la pauta de los castellanos, como en términos de iniciativa, pues los bilbaínos son generalmente huéspedes o comisionistas de comerciantes foráneos. Si medimos la talla de los negocios por el valor de facturación, resulta ser relativamente pequeña, tanto si la comparamos con las grandes casas comerciales castellanas como con los mercaderes franceses, con quienes operan los bilbaínos ejerciendo funciones con diverso grado de protagonismo y que en cierto modo podríamos llamar subordinadas. En realidad, los comerciantes castellanos y franceses aparecen como los verdaderos y últimos emprendedores de la mayor parte de los intercambios, dado que los bilbaínos participan en las importaciones mayoritariamente por cuenta ajena, como huéspedes, factores estables o comisionistas eventuales. Si los bilbaínos cultivan una actividad mercantil autónoma, por cuenta propia en su mayor parte y en compañía de un socio todo lo más, es en el capítulo cuantitativamente menor de las mercancías domésticas como el hierro y el acero destinados a la exportación.

A partir de estas posiciones tan alejadas por el momento de los comerciantes castellanos, a quienes sirven y emulan, los comerciantes de Bilbao 
irán adquiriendo con el paso del tiempo la experiencia profesional, el capital humano y los recursos financieros, propios y ajenos, que les han de permitir en el futuro aprovechar los cambios económicos y fiscales más propicios para escalar nuevas posiciones y ejercer nuevas funciones en el panorama siempre cambiante del comercio exterior español.

\section{BIBLIOGRAFÍA}

ANGUlo, A. (2005): "En poco tiempo vienen ricos e hacen a sus amos pobres". De factores o encomenderos a protagonistas directos del gran comercio internacional (siglos XV-XVII)», en E. García Fernández (ed.), Bilbao, Vitoria y San Sebastián: espa cios para mercaderes, clérigos y gobernantes en el Medievo y modernidad, Bilbao: Universidad del País Vasco.

Azaola, J. J. (1976): «Elementos de análisis cuantitativo de los registros privados: ejemplo de los registros Ruiz de Nantes». Actas de I Jornadas de Metodología aplicada a las Ciencias Históricas, Santiago de Compostela: Publicaciones de la Universidad de Santiago de Compostela, pp. 781-793.

BARKHAM, M. M. (1990): Shipowning, shipbuilding and trans-atlantic fishing in spanish basque ports, 1560-1630: a case study of Motrico and Zumaya. Ph.D. Cambridge: University of Cambridge.

BilbaO, L. M. (1976): Vascongadas 1450-1720. Un crecimiento económico desigual. Tesis doctoral: Universidad de Salamanca.

- (2003a): «El comercio marítimo de la Villa de Bilbao en el comercio cantábrico del siglo XVI». Bidebarrieta, Revista de Humanidades y Ciencias Sociales de Bilbao, vol. XII, pp. 225-2.

- (2003b): «Comercio y transporte internacionales en los puertos de Vizcaya y Guipúzcoa durante el siglo XVII (1600-1650). Una visión panorámica». Itsas Memoria. Revista de Estudios Marítimos del País Vasco (4), pp. 259-285.

- (2004): «El ascenso mercantil del País Vasco en los siglos XIII al XVII». Cuadernos de Alzate. Revista vasca de la cultura y las ideas (31), pp. 143-172.

Bilbao, L. M., y Fernández de Pinedo, E. (1994): «Wool exports, Transhumance and Land Use in Castile in the Sixteenth, Seventeenth and Eighteenth centuries», en I. A. A. Thompson y B. Yun Casalilla (eds.): The Castilian Crisis of the Seventeenth Century. New perspectives on the economic and social history of seventeenth-century Spain. Cambridge: Cambridge University Press, pp. 101-114.

CASAdo Alonso, H. (1991): "Finance et commerce internationale au milieu du XVIe siècle: la compagnie des Bernuy». Annales du Midi, t. 103, núm. 195, pp. 339-340.

- (1994): «El comercio internacional burgalés en los siglos XV y XVI». Actas del V Centenario del Consulado de Burgos, Burgos, vol. 1, pp. 175-247.

- (1995): «Las colonias de mercaderes castellanos en Europa (siglos XV y XVI)», en H. Casado Alonso (ed.): Castilla y Europa. Comercio y mercaderes en los siglos XIV, XV y XVI. Burgos: Excma. Diputación de Burgos, pp. 15-56.

- (1997): "Crecimiento económico y redes de comercio interior en la Castilla septentrional (siglos XV y XVI)», en J. I. Fortea Pérez (ed.), Imágenes de la diversidad. El mundo urbano en la Corona de Castilla (s. XVI-XVIII), Santander: Universidad de Cantabria, pp. 316-322.

- (2000): «Le commerce des «marchandises de Bretagne» avec l'Espagne au XVIe siècle». Annales de Bretagne (107), núm. 2, pp. 29-50. 
FERNÁNDEZ DE PinEDo, E. (1983): «Estructura de los sectores agropecuario y pesquero vascos (1700-1870)», en Antecedentes próximos de la sociedad vasca actual. Actas del IX Congreso de la Sociedad de Estudios Vascos, San Sebastián: Sociedad de Estudios Vascos, pp. 95-108.

- (1998): «Los altibajos mercantiles del Consulado de Bilbao en los años 80 y 90». Las Sociedades Ibéricas y el Mar a finales del siglo XVI, t. IV, La Corona de Castilla, Madrid: Sociedad Estatal Lisboa'98, pp. 115-135.

García de Cortázar, J. A. (1966): Vizcaya en el siglo XV. Bilbao: Caja de Ahorros Vizcaína.

González Prieto, F. J. (2006): La ciudad menguada: Población y economía en Burgos, siglos XVI y XVII. Santander: Universidad de Cantabria.

Graffe, R. (2005): Entre el mundo Ibérico y el Atlántico. Comercio y especialización regional, 1550-1650. Bilbao: Diputación Foral de Bizcaya.

Guiard, T. [1913 (1972)]: Historia del Consulado de Bilbao. Bilbao: La Gran Enciclopedia Vasca.

Hamilton, E. J. [1975 (1934)]: El tesoro americano y la revolución de los precios en España, 1501-1650. Barcelona: Ariel.

Labayru, E. [1900 (1968)]: Historia general del Señorío de Bizcaya. Bilbao: La Gran Enciclopedia Vasca.

LANZA GARCÍA, R. (1997): "Ciudades y villas de la cornisa cantábrica en la Época Moderna», en J. I. Fortea Pérez (ed.), Imágenes de la diversidad. El mundo urbano en la Corona de Castilla (s. XVI-XVIII), Santander: Universidad de Cantabria, pp. 165-200.

- (2002): "Auge y declive de las Cuatro Villa de la Costa en la época de los Austrias", en J. I. Fortea (ed.), Transiciones. Castro Urdiales y las Cuatro Villas de la Costa de la Mar en la historia, Santander: Universidad de Cantabria, pp. 93-138.

LAPEyre, H. (1955): Une famille de marchands: les Ruiz. Contribution à l'étude du com merce entre la France et l'Espagne au temps de Philippe II. Paris: SEVPEN.

- (1956): «El comercio de Bilbao en el siglo XVI». Curso de conferencias sobre cuestio nes históricas y actuales de la economía española, Bilbao: Universidad de Valladolid. Facultad de Ciencias Políticas, Económicas y Comerciales de Bilbao, pp. 781-793.

- (1981): El comercio exterior de Castilla a través de las aduanas de Felipe II. Valladolid: Universidad de Valladolid.

Marcos Martín, A. (1978): Auge y declive de un núcleo mercantil y financiero de Castilla la Vieja. Evolución demográfica de Medina del Campo durante los siglos XVI y XVII. Valladolid: Universidad de Valladolid.

- (2000): España en los siglos XVI, XVII y XVIII. Economía y Sociedad. Barcelona: Crítica.

Mauleón Isla, M. (1960): La población de Bilbao en el siglo XVIII. Valladolid: Universidad de Valladolid.

Maza Solano, T. (1957): "Manifestaciones de la economía montañesa desde el siglo IV al XVIII». Banco de Santander, 1857-1957. Aportación al estudio de la historia econó mica de la Montaña, Santander: Banco de Santander, pp. 81-477.

Pérez Hernández, S. (2005): “Porque asy conbenia al bien de dicha villa”: cambios políticos en Bilbao (siglos XV-XVI)», en E. García Fernández (ed.), Bilbao, Vitoria y San Sebastián: espacios para mercaderes, clérigos y gobernantes en el Medievo y Modernidad, Bilbao: Universidad del País Vasco.

Phillips, C. R., y PHILlips, W. D. (1997): Spain's Golden Fleece. Wool Production and the Wool Trade from the Middle Ages to the Nineteenth Century. Baltimore: Johns Hopkins University Press (edición española, El toisón de oro español: producción y 
comercio de lana en las épocas medieval y moderna, Valladolid: Junta de Castilla y León, 2005).

PriotTi, J.-Ph. (1993): «Nantes et le commerce atlantique: les relations avec Bilbao au XVIe siècle». Annales de Bretagne, núm. 3, pp. 265-28.

- (1995): «Mercaderes vascos y castellanos en Europa durante el siglo XVII: cooperaciones y rivalidades», en H. Casado Alonso (ed.), Castilla y Europa. Comercio y mer caderes en los siglos XIV, XV y XVI, Burgos: Excma. Diputación Provincial de Burgos, pp. 265-283.

- (2004): Bilbao et ses marchands au XVIe siècle. Genèse d'une croissance. Lille: Septentrion P.U. (edición española: Bilbao y sus mercaderes en el siglo XVI. Génesis de un crecimiento, Bilbao: Diputación Foral de Bizcaya, 2005).

Rorke, M. (2006): «English and Scottish Overseas Trade, 1300-1600». Economic History Review, LIX, 2, pp. 265-288.

Sánchez Muñoz, M. P. (2007): El comercio exterior de España, Teoría y Práctica. Madrid: Pirámide.

SPOONER, B. (1972): The International Economy and Monetary Movements in France, 1493-1725. Cambridge, Mss.: Harvard University Press.

TANGUY, Jean (1956): Le commerce du port de Nantes au milieu du XVIe siècle. Paris: Armand Colin.

URIARTE, C. (1999): Un negocio y un modo de vida en el siglo XVI. La compañía de García $y$ Miguel de Salamanca (1551-1574). Tesis Doctoral en Microforma, Bilbao: Universidad de Deusto.

- (2006): «Los negocios de Martín Sáez de Anuncibay a mediados del siglo XVI». Bidebarrieta, 17, pp. 29-49.

Zabala, A. (1994): Mundo urbano y actividad mercantil. Bilbao 1700-1810. Bilbao: Diputación Foral de Vizcaya. 